\title{
The Importance of Corporate Models: Economic and Jurisprudential Values and the Future of Corporate Law
}

Benedict Sheehy

Follow this and additional works at: https://via.library.depaul.edu/bclj

\section{Recommended Citation}

Benedict Sheehy, The Importance of Corporate Models: Economic and Jurisprudential Values and the Future of Corporate Law, 2 DePaul Bus. \& Com. L.J. 463 (2004)

Available at: https://via.library.depaul.edu/bclj/vol2/iss3/4

This Article is brought to you for free and open access by the College of Law at Digital Commons@DePaul. It has been accepted for inclusion in DePaul Business and Commercial Law Journal by an authorized editor of Digital Commons@DePaul. For more information, please contact digitalservices@depaul.edu. 


\title{
The Importance of Corporate Models: Economic and Jurisprudential Values and the Future of Corporate Law
}

\author{
Professor Benedict Sheehy*
}

Every school of thought is like a man who has talked to himself for a hundred years and is delighted with his own mind, however stupid it may be.

J.W. Goethe, 1817, Principles of Natural Science

\section{INTRODUCTION}

Corporate law scholar, D. Millon, in his article "The Ambiguous Significance of Corporate Personhood"1 argues that much of the current debate among scholars concerning the correct or most appropriate model of the corporation is misguided. He argues that the debate is misguided because it contributes little to the understanding of the actual use and operation of the corporation in today's economy. As well, he argues that the debate is not useful, as current jurisprudence seems to have settled on a particular efficiency based model. ${ }^{2}$ Hence, to the extent that the purpose of having the correct model for the corporation is understanding actual use and operation of the corporation, at least some scholars would argue he is correct.

There are various approaches to the corporate model debate. One approach to the debate includes a review of the history of the corporation, noting its privileged and public beginnings, the shift to the registration and limited liability corporations followed by a review of the

* Professor Sheehy teaches corporate and commercial law in the School of Law at the University of Newcastle, Australia. He would like to thank Dr. Helmut Linder of the European School of Business, Reutlingen, and Dr. David Wetzell of the University of the Americas, Mexico for their insightful comments, and Ms. Katharina Mirtsching for help with German law. In addition, he would like to thank the Editor, Paige Barr, for making the publication process simple.

1. David Millon, The Ambiguous Significance of Corporate Personhood, Wash. \& Lee Pub. L. \& Legal Theory Research Paper Series, Working Paper No. 01-6, Jan., 2001.

2. See comment of Chancellor W. Allen, of the Delaware Court of Chancery, America's leading corporate law court, who views the nexus of contracts model of the corporation as "the dominant legal academic view." Stephen Bainbridge, Community and Statism: A Conservative Contractarian Critique of Progressive Corporate Law Scholarship, 82 CORNell L. REV. 856 at n.8 1997 (citing William T. Allen, Contracts and Communities in Corporation Law, 50 WASH. \& LEE L. REV. 1395, 1399 (1993)). 
problems posed by the separation of management and shareholders. ${ }^{3}$ Focusing on such things as legal fictions and nineteenth century legal developments, however, hardly informs or guides issues of the twenty first century. Another approach to the debate, largely informed by political views, is the debate between contractarian and progressive corporate law scholars. ${ }^{4}$ A third approach, which is comprised of an effort to unravel the twisted jurisprudence is unlikely to be anymore fruitful than the historical model debate.

Regardless of what else it is, the corporation is certainly a species of firm-a group of people organized to raise funds and operate a profitable business. 5 The currently dominant model of the corporation, the nexus of contracts model, emphasizes this profit aspect of the firm. These discussions, however, fail to go far enough into the issue. The issue is not "what is the corporation"? For to describe what something is, is not the same as to say what something should be. ${ }^{6}$ This article is an effort to delve more deeply into the model and consider what else the model should be.

The article commences with an introductory review of the current model, noting in particular, its justification in economics. It will then examine the values and assumptions of economics, challenging its claim to provide value-free scientific knowledge. This critique of economic science will lead to a discussion of the role and use of models. Next, the article considers the compatibility of economics with jurisprudence and makes some determinations about the inappropriateness of the economic model dominating corporate law. Having done so, the article will turn to examine some other models that have been more effective in integrating jurisprudential values. Next it will turn to the future and see where corporations are going, asking if the nexus of contracts model will be adequate to deal with those additional chal-

3. This approach seems to be more common among British and Australian corporate law scholars. See e.g., Janet Dine, The Governance of Corporate Groups (2000); Stephen. Bottomley, From Contractualism to Constitutionalism: A Framework for Corporate Governance, Sydney L. Rev. 277 (1997); J. Farrar, Frankenstein Incorporated or Fool's Parliament? Revisiting the Concept of the Corporation in Corporate Governance, 10 Bond L. Rev. 161 (1998).

4. See Paul N. Cox, The Public, The Private and The Corporation, 80 MARo. L. Rev. 391(1997); Bainbridge, supra note 2.

5. Ronald H. Coase, The Nature of the Firm 4 ECONOMIA (NS) 386 (1937) forms the basis for the landmark work in law and economics analysis of corporate law, FrANk EASTERBRoOK \& Daniel R. Fischel, The Economic Structure of Corporate law (1991).

6. This distinction between descriptive or positive and normative is addressed extensively in the realm of science and economics in particular in DANIEl M. HAuSMAN, THE INEXACt AND SEPARATE SCIENCE OF ECONOMICS, (2002). See his first reference to the matter at p. 5. This theme will be picked up and dealt with in greater detail within. 
lenges. Finally we will propose a few modifications that a new model should perhaps include.

\section{Nexus of Contracts: The Current Model}

The model currently in vogue is the nexus of contracts model. ${ }^{7}$ Bainbridge describes the model as follows:

the firm [is] not as a single entity, but is an aggregate of various inputs acting together with the common goal of producing goods or services. Employees provide labor. Creditors provide debt capital. Shareholders provide equity capital, bear the risk of losses, and monitor the performance of management. Management monitors the performance of employees and coordinates the activities of all the firm's inputs. The firm is simply a legal fiction representing the complex set of contractual relationships between these inputs. In other words, the firm is not an individual thing, but rather a nexus or web of explicit and implicit contracts establishing rights and obligations among the various inputs making up the firm. ${ }^{8}$

In this model, corporate law is nothing more than a provider of standard contract terms which are subject to the acceptance of the contracting parties. As there is no such thing as a firm - which is merely a legal fiction-what else can be binding the parties together other than these contracts? Where people are unhappy with outcomes, they simply re-negotiate the contract or leave. In this view there is nothing controversial; everything is voluntary and the wheels of commerce are turning. Members of the corporation, just like members of a church, come and go as they please. This nexus of contracts model is based on an economics analysis of the firm, ${ }^{9}$ and accordingly, to understand what if any controversy there may be, it is necessary to consider the nature of economic science.

\section{Economics: The Discipline}

Over the course of its brief history, economics has developed from its home in the humanities into a social science dealing with decision making and in particular, with predicting behaviour. It is essentially the science developed to analyse the utility of resources, or perhaps more properly, the science of allocation under conditions of scarcity. ${ }^{10}$ Although American economics has by and large failed to address the

7. William T. Allen, Contracts and Communities in Corporation Law, 50 W ASH. \& LeE L. REv. 1395, 1400 (1993).

8. Cox, supra note 4 at 859 .

9. Coase, supra note 5.

10. Lionel Robbins, An Essay on the Nature and Significance of Economic Science (1932). 
epistemological problems inherent to all science, ${ }^{11}$ economics has provided valuable insights into and support for decisions concerning creating a "better society."12

Economists generally assume a utilitarian approach, ${ }^{13}$ using theories to develop models about the way the world works. ${ }^{14}$ It is a longstanding and famous criticism of economics that its modelling and theory are quite removed from experience. ${ }^{15}$ As Nobel Laureate in economics, Ronald Coase, observed:

Economics, over the years, has become more and more abstract and divorced from events in the real world. Economists, by and large, do not study the workings of the actual economics system. They theorize about it. As Ely Devons, an English economist, once said at a meeting "If economists wished to study the horse, they wouldn't go and look at horses. They'd sit in their studies and say to themselves, 'What would I do if I were a horse?'"16

\section{A. Normative or Positive?}

Economics can be either normative or positive although the two are usually combined. ${ }^{17}$ Normatively, economics includes a broad array

11. The dearth of postmodern criticism of economics and general lack of requisite reflection on the foundations of the discipline are nearly incredible to humanists. For an encouraging and interesting tentative step in this direction, see Oxford economist, John Kay's musings Postmodernism, Rationality Management Fin. Times 7 Mar., 2001. American economists since Hutchison, Terrance. The Significance and Basic Postulates of Economics Theory (1938), cited in Daniel Hausman, The inexact and separate science of economics 153 (1992) reflect a reluctance to deal with this as can be seen in their reluctance to face the moral basis fundamental to much of their work.

12. The notion of a "better society" of course begs the questions: Better for whom? And Better by what standard? Hausman, supra note 6 , at 66 . That these questions are rarely forthrightly addressed and debated openly is a fundamental criticism of economics addressed in this paper. For the authoritative work on economics and philosophy see Daniel Hausman \& Michael McPherson, Economic analysis and moral philosphy (1996).

13. Lon Fuller, The Morality of Law 16 (1962); see also Richard Posner, The EcoNOMICS OF JUSTICE 48-60 (2nd ed. 1983) (Posner's discussion comparing economics and utilitarianism).

14. The rather extensive and at times overzealous use of assumptions in economics is a source of criticism both within and outside of the profession. As Cooter and Ulen light-heartedly repeat the comment, "the economist's prediction was correct but the economy went wrong." In COOTER, Robert \& ThOMAs Ulen, LAW AND eCONOMics ix(2nd ed. 1997).

15. See the interesting analysis of economists' mudslinging about theory in U. Maki, Against Posner Against Coase Against Theory, 22 Cambridge J. of Economics 587(1998). See also, U. Maki, Fact and Fiction in Economics: Models, Realism and Social Construction (2002).

16. Hernando de Soto, The Mystery of Capital 15 (2000) (quoting Ronald Coase, THE TASK OF SOCIETY).

17. For a simplified version, see Sir Richard Ivor's discussion on the difference between descriptive and normative economics in law in his Address to Inaugural Law and Economics Course in the newsletter of Law \& ECONOMics Association of New Zealand, Sept. 1997, at 
of values, perspectives and approaches to evaluating and allocating society's resources. It includes ecological ${ }^{18}$ and social values-less often considered part of traditional economic analysis-and is advocated and practiced by a broad range of economists from Amarta Sen, ${ }^{19}$ and Karl Polyani ${ }^{20}$ to Frederick Hayek $^{21}$ and Ludwig von Mises. ${ }^{22}$ Normative economists often evidence some humility, ${ }^{23}$ recognizing that economics is but one of many approaches to addressing the problems of society, and in particular, the economic problems of society. ${ }^{24}$ Normative economists openly seek to make recommendations about policy, and engage other interested parties on the value questions facing society.

By way of contrast, another group of economists claim to be uninterested in the soft stuff of ethics and values and instead claim to be doing pure science. This group describes itself as positivist. It emerged from the philosophers, the logical positivists or empirical positivists, of the early to mid part of the last century. Rather than focusing on theory, the positivists concerned themselves with empirically observable phenomena. Initially, positive economics was a reaction against some of the more philosophically minded economics of the previous century. Positivist economists deny having a political agenda. The champion of positivist economics is certainly Milton Friedman. His 1953 essay, "The Methodology of Positive Economics," 25 was a landmark in the field, which although not well received, was neither challenged successfully nor superceded. ${ }^{26}$ As a result, it remains a standard of economic methodology. ${ }^{27}$

3. Economics is simply put, not well suited to making these types of society shaping judgments.

B. Hsiung's " A Methodological Comparison of Ronald Coase and Gary Becker, AMERICAN LAW AND ECON. REv. 186 (2001).

18. See e.g., Robert Costanza, What is Ecological Economics? 1(1) Ecological Economics 1.7 (1989); Mark Sagoff, The Economy of the Earth: Philosophy, Law, and the EnviRONMENT (1988).

19. Amartya Sen, On Ethics and Economics (1987).

20. Karl Polyani, The Great Transformation (1944).

21. Hayek's devotees have set up a webpage honouring him. See http://www.hayekcenter.org/

22. Von Mises has been taken up as the champion of right-wing, neo-liberals, although it is likely he would not have agreed to any such affiliation. See the website of the Ludwig von Mises Institute http://www.mises.org/.

23. See e.g., Ronald H. Coase, Economics and Contiguous Disciplines, 7 J. of LEGAL ST., 201, 206-207 (1978); Hsuing, supra note 17.

24. Id.; Hsiung, supra note 17 , at 188-189

25. Milton Friedman, Essays in Positive Economics (1953).

26. HAUSMAN, supra note 6 at 163 , and see his note $17 \mathrm{id}$. for a substantial list of rejections of Friedman's work.

27. Indeed, Hausman notes that it remains likely the only work on method that most economists read. Id. 
This distinction between positivist and normative economics, or more accurately between the self-understanding of normative and positivist economists, has created a difficulty in economics. The difficulty is that the barrier between the positive and normative aspects of the discipline is porous and indeed in much of the work of economics the normative aspect is inescapable. As a positive science, economics attempts to explain the laws governing observable phenomena. So, economics attempts to explain the working of markets, decisions concerning allocation of resources and such. Its theories, however, lead to conclusions which easily lead into policy recommendations, and hence positive economics becomes normative. Indeed, even prior to conducting positive analysis, certain value assumptions need to be made, and inevitably taint a "purely scientific" or empirical investigation. Consider the simple example: economists define a certain type of decision as "rational." By definition, decisions that do not meet the criteria are "irrational." 28 Clearly, no responsible policy advisor would advocate an "irrational" policy. So, by creating the definition, the economist has created a norm by which an analysis will be judged.

While within the constraints of economists' definitions of the terms, they are likely correct, the transfer from theoretical investigation to policy advice is highly problematic. Normative prescriptions are political and as such should be debated. This view, however, conflicts with the positivist economists' scientific claims which they say are not political and so not subject to public debate. Accordingly, as just mentioned, economics floats precariously between positive and normative modes seldom clearly separating the two, if indeed, such can be done. ${ }^{29}$

\section{B. Neo-Classical Economics}

One branch of the positivist school, the neo-classical school, has achieved considerable popularity. ${ }^{30}$ Neo-classical economists as positivists claim to be doing value free scientific inquiry ${ }^{31}$ and hence are

28. Hausman, supra note 6 , at 19.

29. Id at 13 .

30. The moniker "neo-classical" is used here to denote economic theory that favours rational choice theory, free markets, and monetary control of the economy. Neo-classical economics is equated with economics generally in this paper because of its predominance and particularly in law and economics. See Hausman, supra note 6, at 3.

31. Indeed, there is no such thing as "value free" science, even in the hard. For the basic philosophical discussion undermining science as a rational progressive enterprise, see Thomas Kuhn, The Structure of Scientific Revolutions (2nd ed., 1970). As an attack on positivist epistemology, the work of C. Levi-Strauss probably serves as a good starting point. Heilbroner attacks the scientific model as appropriate for the study of economics in R. Heilbroner, Visions and Analysis in the History of Economic Thought in P. Porta, ET AL, Knowledge, Social 
not to be accountable or judged by the philosophical mores or concerns of other economists or the larger social debate. Neo-classical positivist economics is perhaps most commonly associated with the New Chicago School after the 1960's. ${ }^{32}$

An important facet of the Chicago neo-classicists is the breadth of application of economic method. It is breath-taking: Chicago economist Gary Becker states, "I am saying that the economic approach provides a valuable unified framework for understanding all human behaviour."33 Neo-classical positive economics tends to lack the humility of normative economics and is fairly subjected to the criticism of "economic imperialism." 34

Contrary to its initial position as a positivist approach (and arguably inevitably) neo-classical economics has moved well beyond positive economics and developed a strong set of normative recommendations about how society should be organized and how resources should be allocated to meet those objectives. ${ }^{35}$

Institutions and the Division of Labour 59-63 (2001). As applied in corporate law, see Thomas W. Joo, Corporations Theory and Corporate Governance Law: Contract, Property, and the Role of Metaphor in Corporate Law, 35 U.C. Davis L. Rev 779 (2002) who observes, "rules of corporate law are often based on social welfare judgments of judges, lawmakers, and regulators rather than on parties' bargains in the marketplace. It misleadingly suggests that the law imposes no value judgments but merely rubber stamps freely made individual decisions. Thus, the model lulls us into thinking we can avoid the hard questions of how the law makes its value judgments." $I d$. at 778 .

32. For a review of economic intellectual history, see Robert L. Heilbroner, The Worldiy Philosophers (rev. ed., 161). For a brief summary of the Chicago School, see New School of Social Research's history of economics website at http://www.cepa.newschool.edu/het/ schools/chicago.htm.

33. Gary s. Becker, The Economic Approach to Human Behavior 14 (1976). Although not all Economists agree with Becker in this respect, most would agree that one can explain much "social" and "political" behavior by reference to the pursuit of one's self-interest. Taken at face value, Becker claims to have outstripped Einstein in finding a unified "theory of everything" (in this case, human behaviour). It is difficult to take Becker's claim as anything more than advancing his political agenda/normative economic vision, since surely he realizes that as it stands it amounts to little more than sophomoric nonsense.

34. Richard Swedberg, Economics and Sociology. In addition, for a criticism of the economic analysis of law, see, for instance, Robert Dworkin, Is Wealth a Value? $9 \mathrm{~J}$. LEGAL Stud. 191 (1980); Robin Malloy, Law and Economics: A Comparative Approach to The. ORY AND PRACTICE (1990); Richard A. Epstein, Law and Economics: Its Glorious Past and Cloudy Future, 64 U. CHI. L. Rev. 1167 (1997): and Martha Nussbaum, Flawed Foundations: The Philosophical Critique of (a Particular Type of) Economics, 64 U. CHI. L. REv. 1197 (1997). As observed by economist, Abba Lerner, "Economics has gained the title of queen of the social science by choosing solved political problems as its domain." Samuel Bowles and Herbert Gintis, Revenge of Homo Economicus: Contested Exchange and the Revival of Political Economy. 7(1) J. of Econ. Persp., 83-102, at 86 (1993) (citing The Economics and Politics of Consumer Sovereignty, 62(2) American ECONOMics Rev. 258-266 (1972)).

35. For discussion of positive economics, see Milton Friedman, Positive Economics in Daniel M. Hausman, ed. The Philosophy of Economics, 210-244 (1990). 


\section{Values in Neo-Classical Economics}

To understand neo-classical economics, one needs to understand its assumptions. These are: ${ }^{36} 1$ ) all human behaviour is individualistic;2) all human behaviour is exclusively self-interested; 3) all human behaviour is rational and humans are no more than "rational utility maximizers";37 4) welfare is merely and wholly the satisfaction of an individual's material preferences; 5) efficiency is the exclusive measure of desirability; and 6) unfettered markets are the best way to permit people to achieve their self-interested objectives, and achieve allocative efficiency. Each of these assumptions has a significant normative implication to which we now turn.

Methodological individualism carries with it the notion that all studies, analysis and recommendations should be designed to enhance individual interests as opposed to those of society. As a result, social interests are either not considered or minimized. In fact, community concerns do not exist for the more thorough-going methodological individualist. Any efforts to promote policies that create a sense of community, solidarity, or coordinated approached to problem solving are actively opposed as "irrational."

The commitment to self-interest as the only motivating force, ${ }^{38}$ also has normative implications. It does not allow for volunteerism, altruism, and such other motives which permit civil society to function. Voting, for example, is a necessary activity to maintain democracy. Yet economists are hard pressed to explain why people vote from the self-interested paradigm. Why would one vote? A single vote is negligible in an election. Even at a theoretical level, economists recognize basic game theoretic problems such as the prisoner's dilemma cannot be solved without cooperation - that is something beyond self-interest. $^{39}$ Nevertheless, because of this self-interested assumption, policies that would promote cooperation and coordination in society are rejected.

36. Hausman, supra note 6 , at 51 sets out seven laws from which are derive the assumptions set out here. The one selected from this set of seven are the ones most crucial to this paper.

37. The famous homo economicus is what I am referring to. For an economist's criticism of this model of human behaviour see Richard Thaler, Homo Economicus, 14(1) J. OF Economic Perspectives 133-141 (2000).

38. Economists have certainly sought other and broader models; however, because of theoretical problems associated with exponential increases in complexity in addition to other concerns have kept other models from being used. See for example of a more complex model Michael C. Jensen \& William H. Meckling. The Nature of Man [sic] J. OF Applied Corporate Finance $4-$ 19 (1994). On the problem generally, see Richard Thaler, supra note 37.

39. See Hausman, supra note 6, at 180-193. 
Positivist commitment to rationality, while appealing at a commonsense level, is highly problematic. Beyond the obvious criticism of common-sense that can be drawn from the comment: "There's only one way of looking at a thing, and that's the right way," 40 it imports other serious, value-laden, and contestable assumptions, not the least of which is that psychologists have demonstrated that humans are unable to make rational decisions without emotions. ${ }^{41}$ Furthermore, the rationality of a thing depends on the correctness and completeness of the assumptions chosen, not to mention the agreement among the economists and policy advisors concerning which assumptions should be chosen in the first place.

As mentioned, generally speaking no one would advocate a policy of irrationality, ${ }^{42}$ but where rationality is too narrowly defined it fails to meet human needs or address human concerns. Human interests in things such as art, entertainment, and leisure are excluded. The policy implications are clear: where something is not "rational" as defined by the economists, it is to be rejected and policies designed to advance "irrational" activities such as art and culture are to be thwarted.

Economists' focus on the satisfaction of individual material preferences has both its own set of assumptions and its own normative policy implications. The assumption is that humans are insatiable: they want unlimited amounts of everything, and then more. It also equates well-being with satisfying material preferences. ${ }^{43}$ This equation of well-being with material possessions is not only empirically, demonstrably completely wrong, ${ }^{44}$ but has two other very unfortunate policy consequences. It promotes over-consumption of the planet's limited resources and ignores the more satisfying contribution of the non-material things such as love, beauty, and mind. It creates pressure to substitute things for people, which of course ultimately leads to a diminished value being placed on people. A life with more things but

40. Elizabeth von Arnim's character Everad favoured this expression in her novel, VerA. Quoted in Monk, Ray. Bertrand Russell: The Ghost of Madness 1921-1970, at 85 (2000).

41. See, for example, the case of "Elliot," an individual who as a result of the loss of emotions, despite a high level of intelligence, found rational decision making nearly impossible. Damasio, Antonio Descartes' Error (1994).

42. Irrationality has been a policy of both Israel and the USA in presenting an image to the world. In the Strategic Command's publication, Essentials of Post-Cold War Deterrence (1995), it was advocated that the United States portray itself as "irrational and vindictive" as "it hurts to portray ourselves as too fully rational and cool-headed." NoAm ChOMSKy \& Edward SAID, Acts of Aggression: Policing "Rogue" States, 29 (1999).

43. Hausman, supra note 6, at 57-59.

44. Daniel Blanchflower \& Andrew Oswald, Money, Sex and Happiness: An Empirical Study, National Bureau of Economic Research, Working Paper 10499 (2004), available at http:// www.nber.org/papers/w10499. 
less people, is a life with more emptiness and depression, which is increasingly common in the developed countries that have focused on having more things. ${ }^{45}$

This focus on material consumption, which follows from equating well-being with consumption, has three policy implications. First, it focuses on facilitating increased consumption as a policy guide or value. Second, it minimizes the value of non-consumables. Third, it focuses policy, logically, on profit maximization, instead of things that truly increase the human sense of satisfaction and happiness.

The neo-classicist economists have selected efficiency as the primary means for society to increase its wealth. ${ }^{46}$ Efficient policies are those that carry the lowest cost, but to do so such policies must promote standardization, decrease diversity, and increase pressure on those effected. This focus on efficiency in process tends to promote a blindness to outcomes. It also devalues people as in the choice between resource conservation and human well-being, it prefers the former over the latter. Policies which do not promote efficiency, while possibly increasing things like equality in society of the quality of life, will be opposed.

Finally, with the view that markets are the best means of distributing goods and services, neo-classical positivists oppose any efforts to create balance or equity in society. Neo-classicists believe that the value of a good is to be determined by examining which party is willing and able to pay the most for it. Thus in any contest, a party with the most money to spend on a thing gets it. There is no allowance for the interests of weaker parties, or parties without resources, or the fact that markets are inherently incomplete. ${ }^{47}$ Distribution of resources has nothing to do with merit or need. ${ }^{48}$ The issue is to maximize wealth in society to permit the maximization of preferences visà-vis goods and services. It favours the war of all against all which in the market context is called "competition."

The constraints imposed by these assumptions cause neo-classical economists to select as their phenomenon of study in wealth and in particular, wealth maximization (although some would argue that neoclassicists are merely arguing utility, for all intents and purposes this

45. Id.

46. Hsiung, The Success of Law and Economics: A Methodological Interpretation 14 (noting "For economists, using efficiency as the criterion of judgment is almost beyond dispute.").

47. Bruce Greenwald \& Joseph Stiglitz, Externalities in Economies with Imperfect Information and Incomplete Markets, 1010:2 QuARTERLy J. OF ECONOMICs, 229 (1986).

48. Neo-classical economics is biased against the less wealth members of society HaUSMAN, supra note 6 , at $58 \& 64$. 
translates directly into wealth). Their modelling and advocacy is focused on wealth maximization as the ultimate objective of social organization. ${ }^{49}$

\section{Additional Problems in Economics}

At this point, of course, economists are no longer engaged in positive economics. Instead, they have moved into normative economics by advancing wealth maximization as society's objective and efficiency as the measure of all things. ${ }^{50}$ What makes this argument about value norms difficult is this conflation of normative and positive economics, and particularly the neo-classical positivist claim of doing value-free science. ${ }^{51}$

To see this conflation of positive and normative economics, consider the example of Kaldor-Hicks efficiency. Neo-classical positivists following Kaldor-Hicks efficiency advocate transacting all transactions that results in increased total wealth, regardless of the desires of the parties and without compensation to the losing party. ${ }^{52}$ From the perspective of the neo-classicist, there is nothing controversial about this advocacy; there is nothing to be discussed. The proposed transactions, a) increase wealth, and b) are efficient. Think of the contrary: Who prefers decreased wealth and inefficiency?

What they fail to mention is that the wealth created through these transactions is it increases wealth concentration. This increased concentration results because where other efficiency measures are applied to the transaction, whose measurements require wealth gains be distributed to all parties, the number of transactions drops to nearly nil..$^{53}$ Kaldor-Hicks efficiency, which permits one-sided, non-compensated gains, was adopted as the appropriate model and such efficient trans-

49. See for example, Pareto efficiency or Kaldor-Hicks theorems. See also PosNer, supra note 13 at $88-119$.

50. One very important consequence of this position is that it implicitly validates the existing distribution of wealth. They oppose all attempts at reallocation as "rent-seeking and rentkeeping."

51. See for example, Posner's claims concerning his use of Pareto efficiency or Kaldor-Hicks theorems, POSNER, supra note 13 at 88-119. Concerning the conflation of positive and normative economics, see Daniel M. Hausman \& Michael McPherson, Taking Ethics Seriously: Economics and Contemporary Moral. Philosophy 31 (1993).

52. See the discussion of Kaldor-Hicks efficiency in Matthew Adler \& Eric Posner eds., Cost-Benefit Analysis: Legal, Economic and Philosophical Perspectives (2000), Kaldor-Hicks as applied in Calabresi and Malamed's view of property law in Guido Calabresi \& Douglas Malamed, Property Rules, Liability Rules and Inalienability: One View of the Cathedral 85 Harvard L. Rev. 1089 (1972).

53. Hausman, supra note 6 , at 60-64. 
actions were advocated, regardless of the injustice done to the noncompensated parties.

The other contestable claim is that no one prefers inefficiency over efficiency. Consider, however, that the value of efficiency in killing a group of people targeted for execution. It depends completely on the perspective. From the perspective of the killers, efficiency is an important value. From the perspective of the victims, inefficiency is the highest value. The value of efficiency, therefore, depends on the ends which it seeks to achieve as well as the perspectives one takes. Furthermore, it is generally recognized that efficiency is not an ultimate end. It is an immediate end. That is, the value of efficiency is not efficiency itself, but as a means to a more desirable end, whether it be more chocolates or a faster firing gun.

Thus, while efficiency is clearly an important value, ${ }^{54}$ it can hardly be the fundamental or organizing value or principle of a society. ${ }^{55}$ In Sir Richard Ivor's understatement: "A society where everyone is intent on maximizing their own wealth has its limitations."56 Efficiency may require killing off the excess humans or enslaving some other humans. ${ }^{57}$ Even neo-classicist Chicagoan, Milton Friedman acknowledges efficiency cannot be the driving force of society. He wrote, "I would favour a free society even if it were less productive than some

54. Hsiung observes that "For economists, using efficiency as the criterion of judgment is almost beyond dispute, but for some legal scholars at least, they find it difficult to accept the idea of efficiency as applied to studying legal studies." Hsiung, supra note 46 at 14.

55. Societies have been organized around religion, social class, social relationships, artistic ability, warriors' power etc. It is important to recognize that each of these societies considered itself to be "the best, most advanced etc." This recognition must bring a bit of humility to our evaluation of our economically driven society. See Francis FukUyama, The END of History And The Last MAN (1992), and particularly his concluding chapter.

56. Ivor, supra note 17 , at 3 . Posner would argue not only that it is possible, but that society in fact does organize itself and its laws on the basis of efficiency. See his chapters " $A$ Theory of Primitive Society" and "The Economic Theory of Primitive Law" in POSNER, supra note 13, at 146-173 and 174-206 respectively.

57. Posner recognizes this as a valid criticism of traditional utilitarian based economics in PosNER, supra note 13 , at 54 . While his theory successfully dodges this problem with utilitarianism, its error is equally egregious if not more pernicious in restricting all discussion and allocation of the world's resources to those with the sufficient economic resources to acquire them. Posner argues that he and his fellow court of appeal judges are just average, ordinary citizens. It is hard to imagine how a person who could afford a minimum of seven years education, practice law for the requisite period earning an average lawyer's salary, and have the political connections and prestige to be appointed appeal court judges are to be considered simply the average person. For further discussion and a more fundamental criticism of Posner's view see those raised by Neil S. Siegel, Sen and the Hart of Jurisprudence: A Critique of the Economic Analysis of Judicial Behavior, 87 Calif. L. Rev. 1581 (2000). 
alternative-say a slave society. . . because my basic value is freedom itself." 58

The problem, quite simply is that all the neo-classical positivists' prescriptions for social organization revolve around increasing wealth by increasing efficiency. ${ }^{59}$ Any brake on efficiency is seen as wrong, erroneous, unscientific, and directing society down the wrong path. It is "irrational."60 If scientists were to use the language of ethicswhich they sometimes slip into-they would argue that inefficiency is an immoral, evil waste of money. While there is certainly some validity to seeking ways to increase a society's wealth and not squander resources, to ignore all other values, including justice, mercy, happiness, freedom, security, and welfare in the process is certainly a roadmap to social disaster. ${ }^{61}$

Yet, for neo-classical economists, the ultimate end-the increased monetary wealth in society ${ }^{62}$-is the sole, exclusive and ultimate Good. ${ }^{63}$ This "social" outcome is a rather curious conflation, if not outright contradiction, of the assumption of methodological individualism.

58. Milton Friedman, Free Markets and Free Speech, 10 Harvard J. Law \& PuB. Pol'y 1 (1987). But to be consistent, should not Friedman then be developing an economics based on freedom as the ultimate value instead of efficiency?

59. To argue the opposite-that a society should be organized around creating inefficiencyfails to grasp the point of the discussion. The issue is not whether efficiency is an important value. Rather, the concern is whether is should be the sole or ultimate value or organizing principle of a society.

60. Before concluding that it is "irrational", however, one must consider the nature of rationality in economics, and in particular bounded rationality. Given the limited and imperfect character of the information we possess and the developing understanding of fuzzy concepts and chaos theory, conclusions about "irrationality" should carry a significant caveat-namely, that a choice or decision may be "irrational" but only so in the model being used.

61. Interestingly, one of the supposed champions of neo-classical economists, von Mises considered these values as important and important in economic analysis. His concerns for these values tend to be completely missed by his later admirers who take him to be a neo-liberal, neoconservative economist without social concern. The issues related to social costs were first brought up by Arthur Cecil Pigou which he addressed as externalities. While scientists can hardly be faulted for not addressing such values, the issue of economic science, which deals with such issues, is called into question as we shall see later. Posner has dealt with happiness in his readable and thoughtful criticism of utilitarianism; however, his wealth maximization principle does not address this issue any better-perhaps a criticism he himself recognized. See Posner, supra note 13 , at 52 .

62. Views clarified and argued by POSNER, supra note 13.

63. See Posner, supra note 13, ch. 3, in which he sets out his theory of "wealth maximization" and specifically deals with it in chapter 4 "The Ethical and Political Basis of Wealth Maximization" as an ethical theory, in PosNer, supra note 8, at 48-115 and in Robin Malloy and Richard Posner in Debate: Is Law and Economics Moral? 24 VAL. U. L REv. 147. Interestingly, in his 1997 Oliver Wendell Holmes lectures he denies completely having ethical concerns. His most distinguished opponent, Robert Dworkin, challenges the views expressed in the Holmes Lectures in Robert Dworkin, Darwin's New Bulldog, 111 Harv. L. Rev. 1718 (1998). 
The problem of economics positivism and values is exacerbated in that once neo-classical positivist economists have made their value judgments concerning wealth and efficiency; further discussions of right and wrong, moral or immoral are ignored or dismissed as meaningless. ${ }^{64}$ While appropriate for a science to dismiss such discussion, at least in some views, it is questionable methodologically to deny or stifle the a priori value debate in science, particularly where the selection of values is at the foundation of the method and therefore determinative of outcomes. ${ }^{65}$

Methodologically neo-classical evaluation begins with the status quo as the benchmark. ${ }^{66}$ Next, it selects and delimits a phenomenon for consideration. As a science, it needs numerical data as applying numerical values permits quantification. As Daniel Hausman, a philosopher of economics, states it: "strategies for beating phenomena into mathematically tractable shape,"67 and then creates a mathematical model for establishing a point of reference. Finally, it adopts a value which it uses as a criterion for advocating or opposing a particular allocation, or predicting a particular behaviour. ${ }^{68}$ Each of the steps in the method is an exercise in value selection. Determining the nature of the economic project is a highly evaluative enterprise. ${ }^{69}$

Economics has another fundamental problem when it comes to matters of distribution. In fact, as Kenneth Arrow has demonstrated, one cannot create the conditions for creating an economically equitable distribution. ${ }^{70}$ In other words, the status quo, despite its increasing inequalities, is more equitable from an economist's point of view than any other possible redistribution. This perspective arises not from the reality but from the procrustean constraints of the discipline's perspective, ${ }^{71}$ and with respect to the neo-classical positivists, the previously discussed Kaldor-Hicks efficiency.

64. See e.g., Richard Posner, 1997 Oliver Wendell Holmes Lectures: The Problematics of Moral and Legal Theory, 111 HARV. L. REv. 1637 (1998). Hausman refers to this as "excessive confidence."

65. This stronger view of the role of the researcher's bias interestingly finds its roots in the natural sciences, and particularly with the phenomenon of researcher observation creating the phenomena in subatomic particle physics.

66. HAUSMAN, supra note 6 , at 14 .

67. Id. at 84 .

68. See Hsiung, supra note 46 , at 7-10. Curiously, Hsiung does not identify the value laden activities of selection, delimitation or modeling as part of the economic method.

69. Noted and discussed in Hsiung, supra note 46 , at 10 , note 33 .

70. Hausman, supra note 6, at 64-65 (citing Social Choice and Individual Values (1963); Values and Collective Decision Making, Repr. In Frank Hahn \& Martin Hollis PhILOSOPHY AND ECONOMICS 110-126 (1979)).

71. HAUSMAN, supra note 6 , at 65 . Hausman notes this is a problem resulting from the "impoverished" basis of economic theory, a position, supported by Sen. 
A further problem confronting economic analysis results from the discussion narrowed beyond numerization to discussion of things that can be monetized. ${ }^{72}$ While this limitation may be insignificant in the discussion of economy, there can hardly be anything more significant to a discussion of human life. Health, happiness, family, friends and a sense of fulfilment-the most important things in life-simply are not subject to monetization. ${ }^{73}$ Finally, economists' focus on satisfaction of individual preferences in consumption of goods and services undermines these and other highly valued aspects of human society, including fairness and justice.

Neo-classical positivist economists' selection of a few favoured values protecting the status quo and total rejection of alternative values is highly inappropriate. In the academy it amounts to dishonesty. The discipline most suited to developing value judgments is not a mathematically focused discipline such as economics. Mathematics delivers rules for working with numbers: it does not prescribe how numbers are to be applied to social phenomena. Rather, value judgments are properly the province of philosophers. Although earlier in its history economics was affiliated with philosophy and the humanities, it abandoned that approach in favour of a scientific methodology. ${ }^{74}$ Economists must continue to make value decisions as it is part of their discipline; however, they must abandon their claim to be conducting pure science and producing scientific knowledge. And undoubtedly, the philosophers would be delighted to have further participants in their engaging debates.

Of course, not all economists are blind to this problem in their discipline. As noted economist Robert Heilbroner observes: "economics, in its 'purest' form is intrinsically and inescapably ideological." $75 \mathrm{He}$ goes on to note: "what is essential, then, is to become aware of one's socio-political values, not to pretend they do not exist."76

Although this discussion of values in economics has been somewhat lengthy, it has been necessary as it forms the basis of much of what follows. What is critical to take from the discussion is that economics is not a value free science any more than law is a value free endeav-

72. See discussion of money and monetary system in DE SoTO, supra note 16 at $43-44,63$.

73. Both Posner and Becker recognize the difficulty and overriding importance of non-monetized events and values. They have taken different approaches in dealing with them. Posner has acknowledge them, but largely been silent (see POSNER, supra note 13 at 64). Becker, by way of contrast, has applied his method even to such thorny issues as marriage, family and free time. Gary S. Becker, The Economic Approach to Human Behavior (1976).

74. Heilbroner, supra note 31 .

75. Id. at 63 .

76. Id. at 61 . 
our. Further, the values of economics, although seldom identified and discussed, permeate much western thinking and in particular, as we shall see next, legal development.

\section{LAW AND ECONOMICS}

There are good reasons for connecting law and economics, not the least of which is that law lacks a method, ${ }^{77}$ while economics lacks a particular field. ${ }^{78}$ In fact, the role of economics in legal analysis has blossomed since Coase's critical 1960 contribution "The Problem of Social Cost." 79 In that article he demonstrated that an economic approach to a nuisance problem, instead of a legal approach, led to a different outcome, and more importantly, to more efficient outcome. ${ }^{80}$ In this and other areas of law, this combination of law and economics has produced some good results and as a result it has developed a strong position in the academy. ${ }^{81}$ In fact, it has developed to the point that, as one scholar puts it:

economic analysis in legal scholarship has become so de rigueur that even those who refuse to view economics as the Holy Grail of knowledge are compelled to use economics in their scholarship. ${ }^{82}$

The economics adopted by law and economics scholars tends to be neo-classical positivist economics. ${ }^{83}$ Hence, law and economics scholars both follow and advocate efficiency, individualism, self-interest, materialism, rationalism, markets, and wealth maximization, as the

77. See Wetlaufer's review of the six main approaches (largely mutually exclusive) to legal method in the last century. Gerald B. Wetlaufer, Systems Of Belief In Modern American Law: A View From Century's End, 49 Am. U.L. Rev. 12 (1999).

78. The vast array of approaches of legal method and fundamental disagreements are the topic of a very learned paper by Gerald B. Wetlaufer, supra note 77 and the lack of a welldefined subject matter is discussed in HAUSMAN, supra note 6, at 2-3.

79. Ronald Coase, The Problem of Social Cost, 111 J. of Law of Economics 1 (1960).

80. One can see here already, the normative over-taking the positive and the traditional legal solutions. Interestingly, Coase states that his objective in the article is merely to point out alternative ways of organizing society. He is not concerned that the market should be arranging things nor that efficiency is the correct basis for making judgments in every instance.

81. For an enlightening discussion of this phenomenon, see Hsiung, supra note 46.

82. Alex Y. Seita, Common Myths in the Economic Analysis of Law, B.Y.U. L. Rev. 993, $995-$ 997 (1989).

83. See for a general discussion of the development of economics in expending beyond the Economics Department, and particularly, into law, Hsiung, supra note 46. For some of the criticisms of law and economics see Robin Paul Malloy, Law and Market Economy: ReinterPRETING the Values of LAW and ECONOMY (2001). For a remarkably insightful and thorough article concerning the a priori philosophical and political values and commitments of scholars and relating them to corporate law, see Cox, supra note 4. Unfortunately, law and economics scholars tend to draw their economics from law texts and as a result tend to view the modified economics explanations offered therein instead of seeing what economists and philosophers of economists state. 


\section{fundamental principles of all social organization ${ }^{84}$ and as such are the basis for and purpose of law.}

\section{This meeting of law and arguably outdated 85 neo-classical positive} economics ${ }^{86}$ is seen by some law and economics scholars, including no less a noteworthy than Judge Posner, ${ }^{87}$ as the ideal. In the view of

84. The obsession with size in America, and particularly the idea that larger is better, is subject to many criticisms. In this particular case, one cannot but help make the analogy of craniometry-the "science" of brain size, founded by Paul Broca and Samuel Morton, and the "science" of wealth maximization where in both instances bigger is "better" without a deep understanding what "better" really is. Craniometry disappeared from the academy when it was realized and admitted that the evidence did not bear out the hypothesis. One can only hope that the neo-classicists will have the integrity and graciousness to take note of the evidence and follow that example.

85. See criticisms below concerning postmodernism and economics. Also, see Amartya Sen's criticism of the mechanistic method to economic analysis applied by contemporary economic theory which method he sees as its "major deficiency." Amartya Sen, Ethics and Economics 28 (1987). Douglas A. Kysar, observed, "The preanalytic vision which informed the development of neoclassical thought was that of a world in which human activity was but a tiny fraction of global activity. Human use of resources and production of wastes was considered costless because the regenerative and absorptive capacities of the earth appeared to have no limits. Today, evidence to the contrary arrives with regularity, to the point that the Royal Society of London and the United States National Academy of Sciences issued an unprecedented joint action statement, warning: "The future of our planet is in the balance. Sustainable development can be achieved, but only if irreversible degradation of the environment can be halted in time. The next 30 years may be crucial." In Douglas A. Ksyar, Sustainability, Distribution, and the Macroeconomic Analysis of Law, 43 B.C. L. REv 1, 70-71(2001).

86. The dearth of postmodern criticism of economics and general lack of requisite reflection on the foundations of the discipline are nearly incredible to humanists. For an encouraging and interesting tentative step in this direction, see Oxford economist, John Kay's musings Postmodernism, Rationality Management, FIN. TIMES March 7, 2001. See also R. Rossini Favretti, Interpretation and Representation in the Discourse of Economics, in P. PORTA ET AL supra note 31 .

87. In much of the discussion that follows, I have taken Posner as the leading exemplar of law and economics positivists. As will be evident, my disagreement with Posner about the correct location of efficiency in the schemata of social values, leads to a number of criticisms of his positions. I have made an effort not to fall into the error some scholars engaged in the debate who tend to argue with caricatures of other positions rather than the real positions-an error identified by Cox. Cox, supra note 4 , at 401 . Instead, I have developed my criticisms from reading of Posner. In my reading of Posner's work his views appear to have become reified, more extreme and hence less nuanced over time. This trend makes it more difficult to access and assess his later work and accordingly, most of the discussion below deals with his earlier work, The Economics of Justice. My disagreement with Posner's thinking and views should not be read as a denigration of his clever and thoughtful consideration of the issues he touches. It is an intellectual disagreement, with openness to competing values, much as he demonstrated in his earlier writings. At this time in his career, although not value-free as none of us are, at least he appeared open to considering alternative values, and it is in this spirit that $I$ intend to offer this work and criticism. As Cunningham in his thorough and critical analysis of Posner's claims notes: "no single view or approach endorsed by all proponents of economic analysis of the legal system, one viewpoint has remained the most prominent-that of Judge Richard Posner." Whitney Cunningham, Testing Posner's Strong Theory of Wealth Maximization. 81 GEo. L.J. 141 (1992). A legitimate argument could be made that Richard Epstein also of Chicago and the most cited law and economics legal scholar should serve as exemplar. Available at http:// 
these law and economics scholars, law is the practical application or implementation of economic science. Law allocates costs to where it is most efficient to do so regardless of whether the cost can be borne by the involuntary recipient. ${ }^{88}$ The general idea is to bring scientific certainty, objectivity and impartiality to legal decisions. ${ }^{89} \mathrm{Law}$, as a collection of principles, doctrines, institutions, and enforcement is merely a tool for maximizing the utility of various competing claims and maximizing efficiency. It is the hand-maiden of economics as the best suited among society's tools for making specific decisions and implementing those decisions, giving rise to and increasing society's overall wealth. ${ }^{90}$

\section{LaW And Economics and Corporate LaW}

Corporate law, according to this view is one spoke in the wheel of efficient tools and is to be developed, interpreted and applied extrapolating along this line for the exclusive purpose of increasing the overall wealth in society. This economic role of the corporation is the focus of analysis once one has come to the conclusion that the corporation is merely an economic arrangement and that corporate law is exclusively about increasing efficiency by such things as providing more efficient default contracting, or by facilitating financing. ${ }^{91}$ It is argued that the economic focus increases society's welfare by assisting in fulfilling the obligations of business. ${ }^{92}$ Indeed as argued famously by Milton Friedman, the social good achieved by a business corporation is producing a profit. As he wrote in his controversial 1970 article: "the one and

www.utexas.edu/law/faculty/bleiter/rankings02/most_cited.html. My reason for focusing on Posner is his long career, his efforts to balance and consider his thinking in light of his judicial practice, his prominence in the Law and economics approach as just noted, and his efforts to communicate his views to the non-academic universe make him an important voice for the positivist economics perspective among the populous.

88. This is the fundamental contribution of Coase, supra note 51.

89. MAlloy, supra note 83 at 5 . Again, the idea of any science, let alone a social science, being certain, objective or value-free, no longer has credibility. The foundational work criticizing economics' pretensions to being value-free science was done by Robert Heilbroner, Economics as 'Value Free' Science, 40 Soc. Res. 129 (1973). See discussion of postmodernism above Rossini Favretti, supra note 86. See also the discussion of Critical Theory in David Braybrooke, The Philosophy of Social Science (1987) and various Critical Legal Studies theorists such as Duncan Kennedy.

90. This aspect of Posner's thought are discussed succinctly in Michael Rosenfeld, Pragmatism, Pluralism And Legal Interpretation: Posner's And Rorty's Justice Without Metaphysics Meets Hate Speech, 18 Cardozo L. Rev. 97, 121 (1996).

91. This is the argument in EASTERBROoK, supra note 5.

92. See e.g., Michael C. Jensen, Maximization, Stakeholder Theory and the Corporate Objec. tive Function, 14 J. of Applied Corporate Finance 3 (2001). 
only social responsibility of business-to use its resources and engage in activities designed to increase its profits." 93

In fact, Friedman pushed his argument for a profit focus further when he argued that the fundamental freedom of society is properly equated with the pursuit of shareholder wealth. ${ }^{94} \mathrm{He}$ argued that this profit focus is diametrically opposed to and mutually exclusive of any other corporate social responsibility, including care for the environment, worker health and safety among other objectives. In that same article he wrote: "Few trends could so thoroughly undermine the very foundations of our free society as the acceptance by corporate officials of a social responsibility other than to make as much money for their stockholders as possible." 95

This emphasis on shareholder wealth is one important aspect of economists' support for the nexus of contracts model also known as the shareholder primacy model. The other main supports are economics' methodological individualism and materialism. This model holds, as Friedman advocates, that the only valid focus of managers is the well-being of the shareholders, and more narrowly, only their financial well-being. For all intents and purposes, no other beings, interests, or even times exist. As previously noted, the contractarian model holds that the corporation is nothing but a legal fiction. It is merely freely contracting individuals-their legal equality taken to be identical or irrelevant to actual bargaining equality. The shareholder primacy model places the highest value on the contribution of the shareholders. ${ }^{96}$

Law and economics, however, fails to take note of a critical and fundamental difference between law and economics. As Joseph Singer playfully puts it, drawing from T.H. White's character Balin "There is something important in humanity ... I cannot at present describe it." 97 Singer identifies the issue of fairness as one of law's particular contributions to society and suggests, among other things,

93. The Social Responsibility of Business is to Increase Its Profits, NY Times MAG., Sept. 13, 1970 , at 32-33, 122, 124, 126.

94. A similar view is taken up by business scholars Michael Jensen and William Meckling in an alarmist, radical, and in hindsight clearly incorrect, article Between Freedom and Democracy, THE BANKer, Oct. 1977.

95. Friedman, supra note 93.

96. For a discussion of the two main models see, Benedict Sheehy, Scrooge-the Reluctant Stakeholder: Theoretical Problems in the Shareholder-Stakeholder Debate, 12 U. of MiAmı Bus. L. REV. (2004).

97. Joseph Singer, Something Important in Humanity, 37 HARv. C.R. C.L. L. Rev. 103 (2002) (quoting T.H. WhITE, THE BOOK OF MERLYN. 
that the answers proposed by economists ${ }^{98}$ fail to meet the needs, desires, and aspirations fundamental to human nature. We now turn to examine some of these desires as they are valued and protected in law.

\section{Law and Social Values}

Is arbitration of disputes with an eye to increasing of societal wealth the total or whole and complete role of law? Such a view would hardly appeal to the average citizen. ${ }^{99}$ Indeed, from the perspective of the average citizen, law that only adds and subtracts wealth would be exceedingly strange. Courthouses are not called the "House of Economics" and nor do the scales in the hands of the blindfolded Goddess of Justice, Themis, contain gold coins or stacked dollar bills. Rather, the scales hold a human heart. These figures are symbolic of values other than the neo-classical economists' values of individualism, wealth, self-interest, rationalism, materialism and efficiency. They symbolize something we call "Justice." The difficulty of defining the term justice, although notorious, need not force us to declare it meaningless and throw up our hands in defeat. Rather, it is a vague terma term that by definition is not wholly or readily definable. ${ }^{100}$

Law is concerned not only with economic efficiency, but with things we call retribution, personal responsibility, ${ }^{101}$ fairness, ${ }^{102}$ and a just society. ${ }^{103}$ It is a discipline extending well beyond the horizons of economic inquiry ${ }^{104}$ looking to aspirations for individual human beings and also those some ends for society as a whole. Its framework is not

98. Singer's concern is with welfare economics, and in particular the work of Louis Kaplow \& Steven Shavell, Fairness Versus Welfare, 114 HARV. L. REV. 961 (2001). See Singer, supra note 97.

99. Both law and economics escape the grasp of the average citizen. Law's highly technical reasoning is simply beyond most people's interest or ability, as Posner has noted, and economic analysis is either objectionable or in some models too technical, see Hsiung, supra note 46.

100. On the growing recognition of importance of vagueness in science and mathematics, see the R. Sorenson, Vagueness, Stanford Encyclopedia of Philosophy (Fall Ed. 2001), available at http://plato.standford.edu/archives/fall.

101. The role of personal responsibility in the development of the human personality is central to much philosophy, from the idea of individual responsibility in Aristotle's virtue ethics to the Existentialists' angst and personal quest for meaning, as well as psychology including such thinkers as Karl Rogers and Abraham Maslow.

102. Which includes of course, issues of distribution of resources, an activity greatly assisted by economic analysis.

103. As Rawls observes, "A theory however elegant and economical must be rejected or revised if it is untrue; likewise laws and institutions no matter how efficient and well-arranged must be reformed or abolished if they are unjust." THEORY of Justice 1 (1971).

104. See Thomas Ulen, Firmly Grounded: Economics in the Future of the Law, 3 WIs. L. Rev. 433,436 (1997). 
and cannot be limited to maximizing wealth transactions. As Sir Richard Ivor notes: "there are always policy trade-offs between efficiency, fairness and other individual and community values" with which law must concern itself. ${ }^{105}$ In particular, law cannot be limited to a discussion of how to organize and protect those with wealth. ${ }^{106}$

Some readers may object that this article is not dealing with real law and economics scholars but a mere caricature. ${ }^{107}$ Consider, however, Posner's explanation of value: "The most important thing to bear in mind about the concept of value is that it is based on what people are willing to pay for something rather than on the happiness they would derive from having it." 108 He goes on to explain: "The wealth of society is the aggregate satisfaction of those preferences (the only ones that have ethical weight in a system of wealth maximization) that are backed up by money." 109 Posner's dismissal of those people without resources not "backed up by money" as not valuing goods is difficult to understand and morally unacceptable even by the society he purports to represent. ${ }^{110}$ For example, recent pharmaceutical companies' decision to supply HIV drugs at low cost because of public pressure suggests that maximizing wealth is not a sufficient or acceptable organizing principal or value to many Americans. ${ }^{111}$

From another perspective, one may ask: Does Posner truly expect people to believe that a starving person with no money places less value (in any recognizable sense of the word) on a loaf of bread than a wealthy person who happens to buy a loaf to feed the ducks? ${ }^{112}$ With a swipe of his pen Posner has discounted the concerns of 5.9 billion people simply because they lack the dollars necessary to purchase re-

105. Ivor, supra note 13 , at 1 .

106. See Robert Dworkin, Is Wealth a Value?, 9 J. OF Legal Studies 191 (1980).

107. See criticism noted by Cox, supra note 4 , (his note 47 mentions caricature criticism).

108. Posner, supra note 13, at 60 . Curiously, this explanation of wealth ignores the economic principle established by Daniel Bernoulli concerning the marginal utility of money. That principle is that the value of each additional dollar is less than the one prior.

109. Id. at 61 .

110. At times, Posner suggests he and his fellow Court of Appeal judges are just ordinary folk sharing the values of the majority of society, although he acknowledges at other times he may be out of touch.

111. The drug industry escaped this fate when in 1995 it stopped producing eflornithine, the cure for sleeping sickness, because of the lack of public awareness of sleeping sickness and because it does not strike people in Northern climates. It is estimated that the drug would save the 66,000 people who die of it annually. Production of the drug was restarted when pharmaceutical companies were able to commercialize its hair loss side-effects.

112. Dworkin's criticism of Posner, noted in Posner, supra note 13. See also, Dworkin, supra note 106. 
sources. ${ }^{113}$ Oddly, if one were to consider the issue from a broader perspective, these people have all the same rights, including property rights in the environment, to such things as clean air and water that provide an economic contribution of more than $\$ 35$ trillion $^{114}$ to the world's productive output. It is perhaps instructive to observe that America as the wealthiest country on the planet is also a notoriously disproportionate, over-consumer ${ }^{115}$ and does not pay these 5.9 billion poor people for the use of their property rights in the environment. Nonetheless, Posner and his fellow law and economics scholars are pleased to dismiss the concerns of the poor while using without payment their environmental property.

Law, however, recognizes that human nature is not only self-interested nor wealth driven in a way that economics does not and cannot. ${ }^{116}$ One need look no further than the Steve Martin character in the movie The Jerk for an example that touches legal theory and legal practice and the economic decisions faced in both. In that movie, Martin plays a character who became fabulously wealthy as a result of a quirky invention. In the course of the movie, the wealthy Martin marries, and later, as he loses his fortune, finds himself in a divorce. As he stumbles out of his mansion weeping, he grabs a few items that have meaning or "wealth" for him. He bawls; "All I want is this ashtray, my blanket and a pair of pants." The money involved simply does not interest him.

The neo-classical positivist has difficulty explaining this action. The lawyer acting for Martin, in order to avoid a negligence claim later would have to advise him to consider more carefully his economic

113. Estimates of the world's population are 6.5 billion, of whom $10 \%$ live a "developed" lifestyle-i.e. have the income necessary to support excess consumption. This problem of dismissing the majority has not been resolved by the New Haven Law and Economics scholars. Despite the fact that $2 / 3$ of the USA's wealth cannot be explained by leading economist, Paul Krugman, Bruce Ackerman is content to argue that the real problem facing the USA is how to distribute this awesome amount of money exclusively among Americans. BRUCE ACKERMAN \& Anne Alstott, The Stakeholder Society (2000).

114. Figure from world renowned scientist and ecologist, David Suzuki, in R. Cairney, Suzuki Offers 10 steps to Save the Planet" (Jan. 10, 2003 ) Express NEws, University of Alberta, available at http://www.expressnews.ualberta.ca/expressnews/articles/news.cfm?p_ID=3646\&s=A. D. Kysar, supra note 85, at 40 (citing R. Constanza. et al., The Value of the World's Ecosystem Services and Natural Capital, 387 NATURE 253, 259 (1997) (offering a range of $\$ 16$ trillion to $\$ 54$ trillion)).

115. This is precisely the problem of public goods: over-production \& over-consumption. Other terms could be "non-valuing," or perhaps, "thieves" are better words, although to be a thief in a legal sense, one must have property rights in the commons defined.

116. See the article by Thaler, supra note 37. Exacerbating the issue is its dogmatic application over what is likely too wide a scope. See Hsuing, supra note 17. Other models which include a much broader approach to human behaviour and society, such as that of Amarta Sen, are simply not addressed. 
rights. Nevertheless, should the client Martin persist in this view, the lawyer should not substitute her view of justice, fairness or value for that of the client. And the law does and must take account of these various value systems. Economics cannot. ${ }^{117}$ As Hart has famously said, "law, however, is too important a thing to be left to lawyers."118 Richard Rorty, America's leading philosopher, has said the same concerning philosophers, ${ }^{119}$ and it is undoubtedly true that the value judgments required for policy analysis and society's development are too important to be left to the economists.

\section{JURISPRUdenCE AND CORPORATE LAW}

Bringing the discussion back to the corporation then, it can be seen that the economic analysis of the nexus of contracts corporation does not take into account all of law's separate objectives such as fairness and justice. Further it fails to include a plurality of values. Even a modest review of current corporate law objectives in the United States suggests that it is a plurality of values that forms the basis. Furthermore, these values are not at all in coincidence with one another. Corporate law scholar Eric Orts notes for example, the divided economic object: profit vs. wealth, short vs. long term, central management vs. dispersed capital providers, capital accumulation, protection of investors, ${ }^{120}$ and the protection of other interests ${ }^{121}$ all as interests within the corporation and corporate law.

Corporate law values also conflict internally as they represent different values in the corporation, society and competing policies. Millon, for example, argues that corporate law has at least four norms which extend beyond a reductionist nexus of contracts model. He suggests that it should: (1) promote stable relations between certain non-shareholder constituencies and the corporation, (2) adjust the gains between shareholders and non-shareholders, (3) address the fairness in allocation of transaction costs, and (4) look for ways to

117. For a discussion of Rational Choice Theory in Law and Economics, see Thomas Ulen, Rational Choice and the Economic Analysis of Law, 19 L. \& Soc. InQuiry 487 (1994).

118. H.L.A. Hart, Bentham on Legal Rights, in OXFORd EsSAYs IN Jurisprudence (2nd Series) A. B. Simpson ed. (1973) reprinted in D. Lyons ed., Rights, (1979), at 146.

119. Richard Rorty, Philosophy and Social Hope (1999).

120. These conflicting values are studied empirically in Henry T.C. Hu, Risk, Time and Fiduciary Principles in Corporate Investment, 38 UCLA L. Rev. 277 (1994).

121. Eric W. Orts, The Complexity And Legitimacy Of Corporate Law, 50 WASH \& LEE L. Rev. 1565 (1993). 
include in decision making those most directly effected by such decisions. ${ }^{122}$

Orts adds that following the law is itself an objective which he describes as "modest idealism," 123 and even identifies the ethical dimension of corporate law that allows for non-economic considerations of ethics and justice seen in instruments such as anti-takeover legislation. ${ }^{124}$ Following his remarkable and interesting analysis of corporate legal theory Orts observes:

policies underlying corporate law cannot be reduced to a uni-dimensional value, such as the economic objective of 'maximizing shareholders' wealth' or even, more generally, 'economic efficiency.'125

To narrowly limit discussion and consideration of corporate law to matters of economy and more specifically wealth maximization, therefore, is either an error or a political choice, ${ }^{126}$ and if it is a political choice, it is only correct that it be identified and debated as such. ${ }^{127}$

122. David Millon, New Directions In Corporate Law Communitarians, Contractarians, And The Crisis In Corporate Law, 50 WASH \& LeE L.R. Rev. 1373, 1388.

123. Robert Clark, Agency Costs versus Fiduciary Duties, in John Pratt and Richard Zeckhauser eds., Principals and Agents: The Structure of Business, 55-79 (1984) cited in Orts, Complexity, supra note 121at 1602.

124. Orts supra note 121 . This is a summary of Orts extensive arguments at 1587-1612.

125. Id. at 1612 .

126. Steven Bainbridge explicitly acknowledges his debate with communitarian corporate legal scholars is political. Bainbridge, supra note 2, at 857 .

127. It is most certainly a right of all members of a society to participate in such a debate regardless of their material resources. Briefly, there are at least three bases for acknowledging such rights. First society's members have this right at least to the extent that they live in a democracy. Inexplicably some scholars attempt to hide their politics under the cloak of objective science. This approach is particularly inappropriate where this pseudo-science is translated into public policy and into orthodox business management studies and fed to executives and business students as truth. See for example, business scholar, Michael Jensen. Although Jensen has been vocal in his political leanings in earlier works such as supra note 94 , where he uncritically advocates certain views as apolitical truth, he seems to have dropped any mention of his views and presents his later work, although still, one assumes, informed by the same political views as objective management science. Jensen supra note 92 . Second, humans rarely occupy material resources for more than eighty years. After that time material resources are passed on, dispersed, lost, disposed of, or disintegrate. By way of contrast, the social decisions we make as a society have wide ranging, long-lasting and significant consequences, not only in our lifetimes but lifetimes after our own and indeed may affect the very possibility of life on the planet. Finally, the nature of the discussion must address the public property versus private property debate. At what point, if any, should individuals who control of vast amounts of resources and vast groups of people be regulated by the public? The issue of public and private is addressed considerably in the literature under the rubric of stakeholder modeling. See also Cox supra note 4, Gregory Mark, The Personification of the Business Corporation in American Law, 54 U. CHI. L. Rev. 1441 (1987); James Gordley, The Moral Foundations of Private Law, 47 AM. J. JuRIS. 1(2002). 
From these political debates, appropriate models can and should be developed, which is certainly one of the roles of models. ${ }^{128}$

In order to recognize the important role of models and how they influence both legal thinking and policy making it is necessary to examine briefly the nature of models. We now turn to such an examination.

\section{Models and the Philosophy of Science ${ }^{129}$}

Models have an important part to play in understanding, ${ }^{130}$ whether attempting to understand oneself, ${ }^{131}$ one's community, ${ }^{132}$ or the universe itself. ${ }^{133}$ Generally, models are miniature or simplified representations of structures, systems, or processes. ${ }^{134}$ They provide insight about how things may work, and provide a platform from which it is possible to gain deeper insights and make better predictions, projections and suggestions about how things may work in the future, including very importantly, how modifications to structures, systems or processes may effect their future working. ${ }^{135}$ The first, informative function of models is sometimes described as "descriptive modelling."136 It is particularly useful in natural sciences where descriptive models help explain natural phenomena and permit us to understand

128. This is certainly the case in politics even more than in science. See P. Feyerabend's work on modelling and theory in his work on the philosophy of science. P. FEyerabend, AGAINST METHOD (1975).

129. Although I have chosen to analyze this debate from the perspective of the Philosophy of Science, I wish to draw the reader's attention to an insightful article by Thomas Joo from the perspective of Cognitive Science and Literary Heuristics in Joo supra note 31. Joo suggests that the corporation as a nexus of contracts-i.e. the metaphor of the Firm-is of limited applicability and therefore limited validity in explicating the nature of the corporation. His recommendation of improving the metaphor by considering the property aspects of the corporation deserves serious discussion. An alternative view is taken by Paul Cox who writes "clashing political moralities are imperfectly modeled as a confrontation between 'communitarianism' and the neoclassical economic analysis of the firm" in Cox, supra note 4 at 396.

130. As a curious note, models are not likely exclusive to humans. Psychologist Edward Chace Tolman studying rat abilities in navigating labyrinths, suggested that they create a "cognitive map" or model in order to navigate successfully. E. Tolman, Cognitive Maps in Rats and Men 55 Psych. Rev. 189-208 (1948).

131. Models in psychology.

132. Models in social sciences.

133. Models in physical sciences and religion.

134. See section "Model history is culture history" in Dr. Mueller "The Concept of Model and the Quadruple History of 'Modulu", opening lecture of the 13th International Conference on History and the Philosophy of Science, Univ. of Zurich, 19-22 Oct., 2000 on Scientific Models: Their Historical and Philosophical Relevance.

135. See for an extended discussion, M. Morgan and M. Morrison eds. Models as Mediators: Perspectives on Natural and Social Science (1999).

136. See Braybrooke, chapter "Causal Regularities on the Naturalistic Side" in BRAYBrook, supra note 89 at $20-46$. 
causal connections between such phenomena. In the social sciences, this is the more conservative approach to the scientific endeavour. ${ }^{137}$

The second function of modelling is denominated "prescriptive" modelling. ${ }^{138}$ This type of modelling does not provide the strong causal connection found in the physical sciences. Rather, it provides mere probability in terms of correlational relevance. ${ }^{139}$ That is, it does not provide information that $x$ causes $y$. Instead, it provides information that in the presence of $x$ there is a high likelihood of the presence of $y$. Despite not being able to provide causal explanations, this type of modelling provides valuable insight and guidance in terms of forward research and broader guidance.

Modelling, however useful as a heuristic device, like all human endeavours is value laden, or as discussed by philosophers of science, such as Lacan, "theory-laden." This phenomenon-sometimes referred to as the hermeneutical circle ${ }^{140}$-refers to the cyclical development as each understanding is being built upon the previous understandings, each one supposedly advancing upon the previous understanding, but obviously, to some extent at least guided by the presuppositions, and limitations of the underlying theory. ${ }^{141}$

Model theory is important because it reveals the restrictions and perspectives that models impose. ${ }^{142}$ Consider the restrictions models have imposed historically. When one uses a spiritual model of human beings, illness is the result of demon possession or punishment for moral or spiritual failing. When one uses a biological model that same illness becomes a matter of bacterial or viral infection, or chemical imbalance or other disease. Even a less dramatic change of models within a single discipline can have a dramatic outcome. For example,

137. See Braybrooke's chapters "Three Sides of Social Science" and "Settled Social Rules on the Interpretive Side" in, Id. at 1-19 and 47-67 respectively.

138. See Braybrooke on Social Science Interpretive methods, id.

139. Advances in correlational sciences have been greatly advanced by progress in statistical theory and calculation. See e.g., Wesley Salmon, Statistical Explanation and StatistiCal Relevance (1970).

140. See e.g., the post-Heideggerian hermeneutics tradition as carried on by H. GADAmER, Truth and Method, trans. by J. Weinsheimer, and D. Marshall, (1983) or furthered in post-Marxian critical thought as represented in Jurgen Habermas' work such as Habermas, Jurgen Theory of Communicative Action, 2 Vols., trans. T. mCCarthy, (1989).

141. Essentially, Feyerabend's critique of scientific method. See fEYerabend, supra note 128.

142. Although model theory was central to the debates of the philosophy of science from Ludwig Wittgenstein, Tractatus logico-philosophicus (1921), Rudolf Carnap, Philosophy and Logical Syntax (1935) the term was coined by A. Tarski, Logic, Semantics, Meta-mathematics, (1954/55) and has subsequently formed the basis for much subsequent advance in the study and understanding of scientific method. Cited in Mueller supra note 134. 
changing models had a dramatic impact on medicine in the case of a formerly fatal illness known as "childbed fever."

Women in the nineteenth century who gave birth often died from the associated illness, "childbed fever."143 The Hungarian obstetrician and researcher, Ignaz Semmelweis, observed that women in the Maternity Hospital in Vienna had a higher mortality rate from "childbed fever" than other women in neighbouring clinics, or at home. The model in vogue at the hospital and in the medical community at large suggested that the fever was the result of stale air. As a result of this model, a concerted effort was made by the hospital and medical staff to avoid exposing new mothers to stale air and instead, new mothers were given special access to air from the outdoors.

Semmelweis began to look for other explanations, however, after his male colleague Kolletschka fell ill and died. Kolletschka, who had cut himself in the process of an autopsy he had performed on a woman who had died of childbed fever, died shortly thereafter having succumbed himself to the same symptoms which were diagnosed as caused by childbed fever. Semmelweis, the alert researcher, discarded the stale air model, made the connection between the cut and the illness, which in addition to radically decreasing the deaths from childbed fever, led to the discovery of germs. Had Semmelweis been so committed to his model that contradictory information could not interfere, germs would not have been discovered possibly for several decades. ${ }^{144}$

As this example illustrates, the theory laden nature of the model adopted can have significant impact on what is found. In particular, how scientists deal with phenomena inconsistent with the model can be determinative not only of current findings, but also of future progress, the allocation of resources, to research programs ${ }^{145}$ or traditions $^{146}$ and as a result, the overall direction of the scientific endeavour. ${ }^{147}$

143. Account taken from William Bechtel, Philosophy of Science: An Overview for Cognitive Science (1988). See the first hand account in Ignaz Semmelweis, The Etiology, Concept and Prophylaxis of Childbed Fever, Medicine: A Treasury of Art and Literature 136 (1991) (K. Codell Carter ed., trans., The Univ of Wisc. Press 1983).

144. Kuhn in his discussion of "normal science" contra Popper's suggestion that when falsified, a hypothesis can survive if the secondary premises of the hypothesis is discarded and the principle premise kept. See Kuhn and Popper in Imre Lakatos, \& Alan Musgrave, eds. Criticism and Growth of KNowledge (1970).

145. Id.

146. Larry Laudan, Progress and its Problems (1977); Larry Laudan, A Problem-Solving Approach to Scientific Progress, in Ian Hacking (ED.), SCIEnTific Revolutions (1987).

147. For an interesting, applied discussion of the role of science-whether it is primarily for the discovery of nature's secrets or the domination and exploitation of nature-see Australian 
The celebrated philosopher of science, Thomas Kuhn argues that there are three manners or strategies in science for dealing with the problem resulting from model failure. ${ }^{148}$ Where phenomena are observed that cannot be explained by the model, they can be ignored, used to modify the model, or where the phenomena is too far from the model's descriptive or predictive ability, the model can be discarded and a new model developed. ${ }^{149}$ When a model is beginning to fail the entrenched defenders of the model, who continue to control the power and resources of the discipline-including research funding, faculty positions, and journals ${ }^{150}$ - defend their model at times viciously against the researchers finding contradicting phenomena which undermines the model. The entrenched defenders make efforts to stifle the dissenting researchers' voices. ${ }^{151}$

A critical problem arising from stifling opposing views, as identified by Feyerabend, is that we cannot know what the future will discover and count or value as knowledge, and accordingly, following a dominant model too strictly may retard the advancement of knowledge instead of advancing it. ${ }^{152}$ All knowledge is founded upon cultural assumptions, and these assumptions are value laden. ${ }^{153}$ Feyerabend, a renowned philosopher of science confronted this profoundly first hand while teaching at UC Berkley. He wrote of his experience:

My function was to carry out the educational policies of the State of California which means I had to teach people what a small group of white intellectuals had decided was knowledge. . . In the years $1964 \mathrm{ff}$. Mexicans, Blacks, Indians entered the university as a result of new educational policies. There they sat, partly curious, partly

economist, and former Governor of the Australian Reserve Bank, H.C. COOMBS, THE RETURN of SCARCITY: Strategies fOr AN ECONOMIC Future, Science and Technology-For What purpose? 61-82 (1990).

148. KuHN, supra note 31.

149. Kuhn's seminal work challenging traditional notions of the rational progress of science by model advancement, sets out a theory based on an analysis of the actual development by a review of historical scientific discoveries. Kuhn suggests a five phase development of science: 1) immature science, 2) normal science, 3) crisis, 4) revolution and 5) resolution. See Kuhn, supra note 31 .

150. See e.g., Laudan supra note 144; BRA YBROOKE, supra note 89, at $77-78$ (discussing Pierre Bourdieu, The Specificity of the Scientific Field and the Social Conditions of the Progress of Reason, Social SCIENCE INFORMATION 19-47(1975) (discussing Imre Lakatos, Falsification and the methodology of Scientific Research Programs, IN Lakatos supra note 144)).

151. Kuhn, supra note 31. An interesting example of this opposition occurred in the case of economist, Tibor Scitovsky. Scitovsky was interested in examining and weighing families of preferences. His efforts to do so were challenged, research resources were denied and other efforts were made to thwart him. THE JoYLess ECONOMY: An inquiry into human satisfaction and consumer dissatisfaction (1976).

152. See e.g., FEyerabend, supra note 128.

153. This is Lakatos' idea in his discussion of Theory-laden models. 
disdainful, partly simply confused hoping to get an 'education'. What an opportunity for a prophet in search of a following! What an opportunity, my rationalist friends told me, to contribute to the spreading of reason and the improvement of mankind! I felt very differently. For it dawned on me that the intricate arguments and the wonderful stories I had so far told to my more or less sophisticated audience might just be dreams, reflections of the conceit of a small group who had succeeded in enslaving everyone else with their ideas. Who was I to tell these people what and how to think. ${ }^{154}$

Feyerabend's insight is stunning, particularly in its blunt, critical, and open presentation of his perception of the situation. It is a realization that became a call for much of the academy, and as a result many disciplines have moved from stark rationalism still advanced by neoclassicists into the post-moderism Feyerabend confronted in this period.

Despite this realization among the philosophers of science and many scientists, for many economists, understanding of the role of modelling in science is at best weak. ${ }^{155}$ Friedman for example, wrote: "Important and significant hypotheses will be found to have 'assumptions' that are wildly inaccurate descriptive representations of reality ."156 One cannot help but find it a bit discomforting to have major policy issues concerning the economy and development of society determined on quasi-scientific models we know to be "wildly inaccurate." 157 As another example, the positivist Posner, confusing model and theory, states "A model can be a useful tool of discovery even if it is unrealistic. .. even though its basic premise was false. . . We should be pragmatic about theory." 158 Posner is fundamentally, methodologically wrong. ${ }^{159}$ Scientific theory is not about pragmatism. ${ }^{160}$ It is

154. SCIENCE in a Free Society (1978).

155. See e.g., Richard Rorty's discussion of Nobel Laureate in Physics, Steven Weinberg, in his "Thomas Kuhn, Rocks and the Laws of Physics" 6 COMMON KNOWLEDGE 1 (1997), reprinted in R. Rorty, Philosophy and Social Hope 175 (1999).

156. Milton Friedman, The Methodology of Positive Economics, in Essays IN Positive Eco. NOMICS 23, 30 (1985).

157. Hausamn, supra note 6 , at $163-168$, notes that the accuracy of assumptions is critical in developing well functioning models with particular reference to Friedman's methodology.

158. Richard Posner, The New Institutional Economics Meets Law and Economics, 149 J. of InSTITUTIONAL AND ThEORETICAL ECONOMICS, 77 (1993).

159. See Hausman's discussion. His position concerning Friedman is more moderate than that presented here. HaUSAMN, supra note 6, at 163-68.

160. Posner's inability to put together a credible theory of pragmatism or ethics is skillfully demonstrated by Robert Dworkin in the latter's review of Posner's works Richard POSNER, The Problematics of Moral and Legal Theory (2000) and Richard Posner, An Affair of State: The Investigation, Impeachment, and Trial of President Clinton (2000). Dworkin's critique can be found in Philosophy \& Monica Lewinsky, 47(4) New York Review of Books, 9 Mar., 2000 
about understanding reality, ${ }^{161}$ about getting it right. ${ }^{162}$ The extreme views on economics, and law and economics, embraced by positivists Friedman and Posner demonstrate an incorrect understanding of the nature of modelling despite its centrality to scientific enquiry. ${ }^{163}$

While the internecine battling between academics may, with reason, seem trivial to those outside the academy, the implications of modelling do not stop on the steps of the academy. Where those competing models have an impact on policy and as a result, on society, and even on the planet as a whole, modelling and the scientific process take on a gravity that extends well beyond the academy, even to the most remote corners of the globe. ${ }^{164}$ Where, for example, a country adopts a particular economic model, which carries its value assumption of "economy above all", increased global warming inducing carbon-dioxide emissions which benefit the economy are considered the better choice. ${ }^{165}$ Such is the economic modelling debate, ${ }^{166}$ of which corporate modelling is a very important expression.

As we have seen, there are various value or "theory-laden" aspects to the model discussion and these apply no less to the model developed in law. ${ }^{167}$ A fundamental analysis of legal scholars' prior philo-

161. This is not an adoption of essentialism. Rather, by reality I mean the generally accepted phenomena under study by a group of scientists.

162. Interestingly, jurist $F$. Hallis adopted a similar view of models in "juridical science." Hallis offered: "[1]f therefore juristic concepts are not true universals, they are not pure fictions which have not relation to the true account of the real facts. . . [I]t is a sufficient answer to those who say that juristic science is not concerned with the real nature of social facts, but only with what the lawyer makes of them, to point out that the law has a practical and not a utopian aim." Mark, supra note 127, at 1470 (citing Frederick Hallis, Corporate Personality xvi, xli (1930)).

163. See Daniel M. Hausman's critique of economists understanding or acceptance of scientific method in Philosophy of Economics, in Routledge Encyclopedia of Philosophy, Vol. 3, 211-22.

164. The effects of global warming are being seen, for example, in the isolated communities of the Canadian Artic. Mush at the North Pole in the NY Times T. Friedman in Alaska. See the most recent spate of lawsuits against corporations discussed in A Novel Tactic on Warming, N.Y. Times, July 28, 2004.

165. G.W. Bush stated USA environmental policy in just these terms. In explaining why he rejected Kyoto he stated: "I will not accept anything that will harm our economy or hurt our American workers." "Bush says Kyoto could harm American economy" March 29, 2001 Canadian Broadcasting Corporation.

While it may be argued that climate change may hurt the economy more than polluting will benefit it, because of the economic model used by the Bush Administration, the economic harm is apparently not factored in.

166. In his famous lections on the Industrial Revolution, renowned historian A. Toynbee discussed the economic modelling debate as "Economic Science, and its antithesis, Socialism", LECtures on the Industrial Revolution in England (1884), reprinted as Toynbee, A. The Industrial Revolution 58 (1956), cited in J. Cohen, Revolution in Science 267 (1985).

167. By situating this discussion of legal models after a discussion of scientific models, I am not implying that law is a science. 
sophical and political commitments has been conducted by Professor Cox. ${ }^{168}$ As Cox puts it:

Resolution of conflicting normative visions through law conceived as a political process or dialogue, or as the practical wisdom of legal authority is not a resolution compelled by the norms of our community. Rather, it is a choice of one tradition over another. That choice is not itself justified by reference to the tradition chosen; it is merely explained by reference to the chooser's prior commitment to that tradition. ${ }^{169}$

These prior commitments address the role of the state, the nature of the individual, and the nature of society. ${ }^{170}$ Briefly, for legal scholars, political and philosophical issues identified by Cox are threefold: (1) is the state an inefficient Leviathan of whom we should be sceptical, or is its role to create and mold a better, more humane, more just society? (2) Is the individual a rational self-interest maximizer, or a social being, such as a social constructionists suggest, ${ }^{171}$ bound by the norms of society? And finally, (3) is society a cooperative measure for the good of all, or is it a mere means for individuals to achieve individual ends? ${ }^{172}$

The debate framed as such, with its politics made explicit, becomes potentially one in which the corporation and corporate law become important constituents in the larger enterprise of the understanding and shaping of human society and individuals. This debate requires fundamental value judgments concerning, among other things, the valuing of solidarity ${ }^{173}$ over efficiency ${ }^{174}$ or vice-versa, such things as whose planet the Earth is, and whose interests count, or be ignored. Wisdom in handling models would require one to note Wittgenstein's observation: "Say what you choose, so long as it does not prevent you from seeing the facts (And when you have seen them, there is a good deal you will not say.)"175

As previously noted, models are of two types: descriptive and prescriptive. The debate about models in corporate law has been restricted to the former: it has been a debate about what model best fits the corporation as we have it today in society. From this perspective, the contractarians would appear to be correct as far as they go if one

168. Cox, supra note 4.

169. Id. at 513.

170. The framing of the issues as set in this paragraph is based on Cox's article, is but in no way does justice to the careful and very sophisticated analysis offered by Professor Cox.

171. See Cox, supra note 4.

172. A necessary corollary to the view that there is no such thing as society.

173. Communitarian or Progressive Corporate law scholars.

174. Contractarian Corporate law scholars.

175. Ludwig Wirtgenstein, Philosophical Investigations 79 (3rd ed. 1968). 
agrees to ignore parties whose interests they have chosen not to acknowledge. ${ }^{176}$

The other type of model, the prescriptive, is important in the discussions about law, economics, society and social policy. Society takes note of, adapts to and models itself after the prescriptive model. As a result, prescriptive models often do become descriptive models. ${ }^{177}$ It is in this context, that the question of: "What is the corporation?" is transformed into: "What should the corporation become?" As a result the modelling debate comes into renewed focus. It is at this point that the discussion becomes very interesting and the difference between law and economics comes into even sharper contrast.

\section{Trends and Critiques - Stakeholders AND SHAREHOLDERS}

In North America from the 1930's until the 1970's, the model for the corporation was the communitarian model in which the corporation had some social responsibilities. This model was obtained as a result of the Berle and Means debate "Whom should the corporation serve?"178 which was one result of the economic collapse and Great Depression of the 1930's. The model springs from a broader view of the business corporation and recognizes that in addition to shareholders, other interests, such as those of employees, suppliers and communities are legitimate concerns for corporate executives. ${ }^{179}$

As politics under Ronald Reagan moved in a more conservative direction, however, the corporate legislation followed. ${ }^{180}$ Neo-classical economists' prescriptive model for the corporation, was followed and the move from communitarian to contractarian model commenced. ${ }^{181}$ This focus on wealth generation to the exclusion of all other concerns has been most directly advocated by the Chicago School of which Milton Friedman is a leading spokesperson. In his famous dictum quoted previously, the role of corporate managers is "to make as

176. Steven Bainbridge's article is perhaps the best analysis of this aspect of the contractariancommunitarian debate. Bainbridge, supra note 2.

177. Heuristic and hermeneutical aspects of the model have been discussed above.

178. For a review of the debate, see A. A. Sommer, Whom Should the Corporation Serve? The Berle-Dodd Debate Revisited Sixty Years Later 16 Del. J. CoRp. L. 33 (1991). For a review of the history of these models see William Bratton, The New Economic Theory of the Firm: Critical Perspectives from History, 1 Stanford Law Rev. 1471-527 (1989), in Sally Wheeler Ed., The Law of the Business Enterprise: Selected Essays, Oxford Readings in Socio-legal Studies 117-179 (1994).

179. For a discussion of the models and the thinking underlying each, see Sheehy, supra note 96.

180. L. McQuaig, All You Can Eat 33-39 (2001).

181. See Bratton, supra note 179. 
much money for their stockholders as possible."182 Further, Friedman stated that all calls for corporate social responsibility should be ignored as pernicious and a threat to freedom. ${ }^{183}$ It is important to note that the supposedly value free scientist-economist is advocating particular economic policies on the basis of his philosophical values. Apparently, it is appropriate even from an economist's perspective to inquire about values and in particular which values we wish to pursue as a society, in this case freedom. Interestingly, he does not explain why investors' freedom to invest the excess funds they have available for investment is more important than the poors' freedom from job insecurity or hunger.

In another curious self-contradiction, Friedman and other wealth maximization economists, ${ }^{184}$ implicitly recognize that wealth is not an end in itself. Rather, it is an intermediate end-something that leads to another more desirable end or ultimate end. ${ }^{185}$ According to these economists the overall social good is the ultimate justification for the exclusive focus of corporations on profit. In other words, the good end of social benefit will be achieved by ignoring it and by focusing instead exclusively on another end-shareholder wealth maximization. ${ }^{186}$ These economists are making an old and well known argument. ${ }^{187}$ Their argument, sacrificing individual good for the purpose of creating the greater social good, is the argument advanced by the philosophical school known as utilitarianism, ${ }^{188}$ which coincidentally collides with Friedman's other great concern of freedom. Briefly, how does one sacrifice the individual for the common good while still protecting individual freedom as the ultimate end?

182. The Social Responsibility of Business is to Increase Its Profits, N.Y. MAG., at 32-33, 122, 124, 126 (Sept. 13, 1970).

183. Id.

184. See e.g., Jensen, "value maximization is an important one because it leads. . to the maximisation of social welfare." Supra note 92, at 302.

185. Acknowledged even by POSNER, supra note at 108 and discussed in more detail in Cunningham, supra note 58 , at 164 .

186. This position shows either a remarkable quasi-religious faith in free market economics or a Zen approach to social justice. For a discussion of foundations of the stakeholder-shareholder debate see Sheehy, supra note 96 . This shareholder primacy model is usually advanced by corporate law scholars who consider themselves contractarians.

187. See Walter Sinnott-Armstrong, Consequentialism, The Stanford Encyclopedia of Philosophy (2003); Edward N. Zalta (ed.), available at http://plato.stanford.edu/archives/ sum2003/entries/consequentialism/. Posner's acknowledgement of his "wealth maximization" theory as a refinement of ethical utilitarianism, supra note 13.

188. Utilitarian theory is an important and helpful theory in policy development and analysis. It is not, however, well suited to many matters of concern to lawyers. In particular, utilitarian have struggled to address the problem that the interests of the majority may be at the expense of minorities. 
In the law and economics field, Posner, Epstein and others have advocated wealth maximization as the basic principal of law ${ }^{189}$ and have encouraged legislative and judicial reforms in order to implement efficiency and wealth maximization principals. As applied in corporate law, it supports the shareholder primacy model. ${ }^{190}$

In summary, the economists have made two main claims about the contractarian model of the corporation. First, they have made the economic claim that it will lead to greater benefit of all society. Second, they have made two philosophical or value claims: that the contractarian corporation will lead to greater freedom, and following the economists' bias in favour of material satisfaction, that it will lead to an increased delivery of human welfare ultimately measured by happiness. ${ }^{191}$

Concerning the first proposition, that increasing shareholder wealth benefits all of society, the evidence has not borne out the economists' prediction. As one part of the general neo-classical economic policy prescription for the years from 1980 through to the present the contractarian corporation (and other neo-classical prescriptions) has failed to deliver a wealthier or more just society. ${ }^{192}$ For example, in the USA, as corporations gave up a broader societal focus and turned toward shareholder primacy, the disparity between rich and poor grew, the wealth of the middle class declined, ${ }^{193}$ and corporate monopolization of power increased. ${ }^{194}$

189. Posner, supra note 13, Richard EPSTEIn, Principles for a Free Society: ReconCiling Individual Liberty with THE COMMON GoOd (1998).

190. Most comprehensively put forward by EASTERBrooK, supra note 5.

191. David Blanchflower \& Andrew Oswald, Money, Sex and Happiness: An Empirical Study, National Bureau of Economic Research, Working Paper 10499, (May 2004), http:// www.nber.org/papers/w10499 (last visited Jul. 30, 2004.

192. See for example, the summary of statistics of poverty and homelessness in the United States in Bob Herbert, Change The Channel, N.Y. Times (Dec. 19, 2003).

193. See e.g., David Cay Johnston, Very Richest's Share of Income Grew Even Bigger, Data Show, N.Y. Times (June 26, 2003) (reporting "The 400 wealthiest taxpayers accounted for more than 1 percent of all the income in the United States in the year 2000, more than double their share just eight years earlier,"). Clearly, there are many reasons for such disparities such as government policies, performance of the economy and changes in the labour force resulting from globalization, but the disparity noted parallels the shift away from stakeholder thinking and seems to suggest that shareholder primacy cannot be supported along these lines. See David Millon, Frontiers of Legal Thought: Theories of the Corporation, DukE L. J. 201, 222, 229-230 (1990) on the triumph of shareholder primacy in this era. See also, LudwiG McQuaig, supra note 181 , at $96-107$.

194. The landmark studies are G. Domhoff, William Who Rules America now? (1983), and C. Mills, Wright Power, Politics \& People: The Collected Essays of C. Wright Mills (1963). See also, Charles K. Derber, Corporation Nation: How Corporations Are Taking Over Our Lives And What We Can Do About It (1998). For a flavour of the American public's skeptical opinion on corporate power even in the boom years leading up to 
Further evidence of the effect of shareholder primacy corporations and social wealth on a wider scale comes from the World Bank and the IMF. The structural adjustment programs imposed by these institutions, ${ }^{195}$ an integral part of which have been to open borders to transnational shareholder primacy corporations, have been failures. ${ }^{196}$ The failures referred to here are policy failures, the great hardships they have caused the poor, and the acid test, they have failed to deliver the economic relief for which they were designed. ${ }^{197}$ Worse yet, the costs of these failures have been borne by the poor while increasing corporate profits. ${ }^{198}$ These outcomes would lead one to suggest that the neo-classical corporate law model does not make for a better society. ${ }^{199}$ Simply, their first claim of leading to a greater benefit for all society is unsubstantiated.

The neo-classicist is likely to reply that this conclusion is erroneous as the issue of distribution of benefits is misplaced as a matter of corporate law. Indeed, it cannot be assumed that a consensus exists concerning the equitable distribution of goods. Some will argue that the distribution of resources is irrelevant to the organization of society provided one can justify the status quo. ${ }^{200}$ Others will argue that a just society requires consideration and some adjustment of the distribution of society's benefits. ${ }^{201}$ Yet others argue that absent transac-

the 2001 stock market bubble burst, see the article, Too Much Corporate Power?, Bus. WeEk, (Sept. 11, 2000), available at http://www.businessweek.com/2000/00_37/b3698001.htm.

195. W. Easterly, The Effect of IMF and World Bank Programs on Poverty (2000), available at http://www.imf.org/external/pubs/ft/staffp/2000/00-00/e.pdf. See also Noble Prize Laureate and former chief economist at the World Bank Joseph Stiglitz, Globalization and Its DisconTENTS (2001) and more recently, C. Welch, The Broken Promise of NAFT, N.Y. Times (Jan. 6, 2004) available at http://www.foreignpolicy-infocus.org/briefs/vol5/v5n14sap.html. See also, McQuAIG, supra note 140 , at $82-92$.

196. This failure of the programs is the main theme of Stiglitz book. Id.

197. This is one of former World Bank Chief Economist, Joseph Stiglitz' complaints.

198. Nora Lustig, economist and former Director of the World Bank's World Development Report and non-resident Senior Fellow at Brookings Institute observes that the poor and middle class absorb an inordinate share of the pain of structural adjustments. See her chapter "Social Costs" in Nora Lustig, Mexico: The Remaking of an Economy 61-95 (1992). See also DiNE, supra note 3, at ch. 5 and extensive notes therein. For a recent analysis see Egor Kraev Modeling Macroeconomic and Distributional Impacts of Stabilization and Adjustment Packages: Current Literature and Challenges, CEPA Working Paper 2003-06 (2003), available at http:// www.newschool.edu/cepa/papers/abstract.htm\#200306.

199. A better society in the argument here may be equated with a society which has increased either wealth or happiness. Interestingly, the wealthiest society in the world is far from the happiest. See David Blanchflower \& Alan Oswald, Money, Sex and Happiness: An Empirical Study, National Bureau of Economic Research, Working Paper 10499 (May 2004), available at http://www.nber.org/papers/w10499 (last visited Jul. 30, 2004).

200. See e.g., Robert Nozick, Anarchy, State and Utopia (1974).

201. Coase of course recognized that the real world operates with transaction costs and so that his theorem was merely an analytical tool for wealth maximization. 
tion costs, the initial allocation of social benefits is immaterial. ${ }^{202}$ If, however, we accept that society is for mutual benefit (and this benefit is the neo-classicist justification for shareholder primacy corporations) then we have the appropriate criteria to make a judgment. That judgment would appear to be that the overall economic benefits supposed to come from this prescriptive corporate law shareholder primacy model have simply not appeared.

As to the neo-classicists' second claim concerning the values of increased freedom, and delivering the ultimate good of happiness, again the neo-classicist policies appear to be in error. In this same era of the 1980 's to the present there has been increased pressure on workers to work more hours and take on more responsibility without corollary support-which by reducing costs increases returns to shareholders. It is difficult to see how this increases either freedom or happiness of the majority of the population, namely, the working class. The evidence demonstrates that the shareholder primacy model has not increased social wealth.

In the case of corporate models, it may well be argued that the contractarian model is not producing the predicted results and hence its claims for normative power are unfounded, and it should be modified significantly or abandoned. As this model, however, is interwoven with the values and ideology of neo-classical positivist economics, it is not likely to be either modified or abandoned by these economists. Indeed it is a fair and common criticism of economists that they fail to abandon disproved models or models which regularly fail to deliver predicted results. ${ }^{203}$

If economics is indeed a science, as it claims to be, then it must be acknowledged that an unshakable faith in a model is a religious position rather than a scientific one. ${ }^{204}$ Science and the scientist must deal with their models in light of the evidence, rather than the reverse. ${ }^{205}$ In the face of intransigence it is incumbent on other scholars party to the debate to increase pressure to bring about a change.

202. These thinkers would be neo-classical economists following Coase.

203. Hausman comments on this counter factuality and economists difficulty in dealing with it in his chapter "On dogmatism in economics: the case of preference reversals," in HaUsmaN, supra note 6. Again, it is the same phenomena that seems to frustrate Stiglitz who refers to these neo-classicists as "market fundamentalists." Stiglitz, supra note 196, at 14.

204. John Kenneth Galbraith views the changes in his opinion in this light. Stephen P. Dunn, "The Origins of the Galbraithian System: J.K. Galbraith" interview with J.K. Galbraith, 2001.10 Division of Economics at Staffordshire University Business School, available at http:/ www.staffs.ac.uk/schools/business/economics/papers/ec2001-10/pdf.

205. This is indeed Coase's point in the discussion above. 
Still, economists are correct as far as they go-that society is for improved material benefit. ${ }^{206}$ Social contractarians have made this argument in various forms for centuries. ${ }^{207}$ Economists, however, fail to go far enough. As Rawls pointed out nearly thirty years ago, the second pillar of the social contract is justice in economy. ${ }^{208}$

Economics, as some economists readily acknowledge, ${ }^{209}$ does not hold all the answers and legal scholars should not be seduced into following that lead too quickly or unquestioningly. ${ }^{210}$ As Orts in his detailed analysis of normative corporate law observes, "Corporate law, like most law, is primarily about the rule-oriented structuring of social power, and it is specifically about the rules that structure the organization of economic power."211 Following Rawls, therefore, a compelling argument can be made that corporate law should include access to power by non-shareholders. ${ }^{212}$

As a start, therefore, legal scholars should be developing a model that enhances access to economic power for more parties. Friedman's and other neo-liberal economists' dislike of intrusions on "freedom" 213 cannot be restricted to preserving freedom for those wealthy and powerful enough to afford it. Hardly anyone would be willing to see a return to the pre-suffragette or pre-emancipation USA. ${ }^{214}$ Yet the contractarian model is just that-a regressive concentration of power and wealth in the hands of the few under the guise of freedom. This issue is certainly an issue of modelling.

Just as the economists at the World Bank are asking themselves, what then is the alternative model for development loans and govern-

206. Rawls argues this as his first principle of social organization. But this is a modern, western view. Conflicting views are presented in a broad historical context in JARED DIAMOND, Germs, Guns, and Steel: The Fate of Human Society (1996).

207. Philosophers of highly divergent views have made the Social Contract argument from John Locke and Jean Jacques Rousseau, to the present day John Rawls.

208. Rawls, supra note 103, at 4 and discussed in detail at 60-75, and 90-95.

209. Discussed in Hsuing, supra note 17 , at 187 n.2.

210. Some economists plainly admit the fundamental role of values in their studies. See e.g., J. Wolfenden, Homo economicusI: Fantastics Fact or Factual Fantasy?, 1(2) Ethos-A JournaL of Global Ethics (1998) (citing Lipsey \& Chrystal, An Introduction to Positive EcoNOMICS 28,8 TH ED.).

211. Orts, supra note 121 , at 1577.

212. See the suggestion by Shun Wilson Leung, The Inadequacy Of Shareholder Primacy: $A$ Proposed Corporate Regime That Recognizes Non-Shareholder Interests, 30(4) ColumbIA J. LaW ANd Social Problems 587 (1997).

213. Flexibility in approaches to problems is indeed Coase's point in the discussion above. For example of an alarmist, libertarian appeal supporting shareholder primacy see, Jensen, supra note 94.

214. Michael Parenti, A Constitution for the Few (1988). In particular, see excerpt in T. SImon, Law \& Philosophy 172-177 (2003). See also Cunningham, supra note 58 (discussing the economics of slavery). 
ment restructuring, ${ }^{215}$ legal scholars need to be examining more carefully alternative models for corporations that both enhance social justice and economic needs. ${ }^{216}$ Legal scholars should be asking important questions such as what objective should a new prescriptive model include? And then, of course, look at developing new models that would more effectively include those objectives. For legal scholars to adhere to the shareholder primacy or contractarian corporation model is a breach of professional responsibility. Lawyers and legal scholars must be concerned with issues of ethics and justice. As noted at the outset of this paper, it is not sufficient to take Chancellor William Allen's previously mentioned observation that the contractarian model of the corporation is "the dominant legal academic view" 217 and end the discussion. Describing what is cannot be the same as saying what should be.

Other models that have done somewhat better in terms of achieving better social ends are those found in Europe, and in particular Germany, and in Japan. ${ }^{218}$ The models followed in those countries have included other interests such as labour and collaborating companies.

\section{Corporate Models for the Future}

Regardless of one's political and philosophical commitments it is evident that corporations, with their concentrations of wealth and resources, and as the major source of employment, are the major drivers and controllers of the economy, culture, and environment. Joseph Stiglitz, former World Bank Chief Economist, and Nobel Prize in Economics winner explains that the importance of decisions about market models can hardly be overstated.219 By their association and critical role in market making and domination in the market, the importance of corporate models is hard to overstate. Not only will they have con-

215. Possibly, new answers could arise if the science of economics is at another point of revolution. Cohen, citing John Hicks notes various revolutions in the science of economics, including a current movement away from Keynesian economics. Cohen, supra note 131, at 558559. From J. Hicks, 'Revolutions' in Economics, in Latsis, SPIro ed. Method and APPraisal IN ECONOMICS 207 (1976).

216. These are not necessarily conflicting norms. See e.g., JAN Hogendorn, Economic Development, 3rd ed. (1996).

217. See Allen, supra note 7.

218. As distasteful as it may be to some market economists, it must be recognized that China's communist centrally controlled economy has been credited with saving millions from starvation which would otherwise have arisen under capitalist market conditions. This is not to say that China has not also caused famine and suffering among its people. See, for example, the discussion in Vaclav'Smil, China's Great Famine: 40 years Later-Education and Debate (Dec, 18, 1998), available at http://www.findarticles.com/p/articles/mi_m0999/is_7225_319/ai_58614609. British MED. J. observes the political causes of China's previous great famine.

219. Stiglitz, supra note 196, at 217. 
siderable bearing on the overall economy but also on the development of societies throughout the world. They have great power to influence such important things as global warming, ${ }^{220}$ wilderness preservation, ${ }^{221}$ and even warfare. ${ }^{222}$ Before considering what models should be considered for the future, a very modest review of contemporary models and their respective strengths and weakness may serve as a springboard for moving our thinking forward. In this section, I do not intend to conduct the standard review of models of corporate governance, which Australian corporate law scholar, John Farrar, notes as a comparative approach in the 1980's. ${ }^{223}$ I am interested instead in the different models as they address other matters, such as social costs. That discussion will be followed by a brief review of two management scholars' views of future corporations and the significance of those ideas for future corporate law development.

\section{A. Anglo-American Model}

The distinctive aspect of Anglo-American model is its "shareholder primacy." Shareholder primacy places the interests of the shareholder above all others, and as we have seen even to the exclusion of all other interests. ${ }^{224}$ Other interests which are ignored include such things as the social costs, ${ }^{225}$ environmental costs, and employee needs. Every cost the Anglo-American corporation can avoid, it does avoid in order to return more money to the shareholders. Every benefit it can appropriate, it does without regard to ensuring "there is enough, and as good left in common for others." 226

220. One can examine, for example, the lobby efforts of the automotive and petroleum industry against reduction in greenhouse gas-emission legislative proposals.

221. See the controversy surrounding the Bush administration's proposal to explore in the Artic Reserve.

222. The author is referring to the infamous military-industrial complex.

223. John H. Farrar, In Pursuit of an Appropriate Theoretical Perspective and Methodology for Comparative Corporate Governance. 13 Aust. J. OF CORP. LAw 1, 9 (2001).

224. Merton Miller, Is American Corporate Governance Fatally Flawed? chapter in DonalD Chew ed., Studies in International Corporate Finance and Governance Systems: A Comparison of the US., Japan, AND Europe 38 (1997).

225. Social costs include things as harm to consumers, and "social capital" discussed for example, in Paldam, Social capital: One or many? Definition and measurement, 14(5) J. of ECONOMIC Survers, 629-653 and in M. Fafchamps \& B. Minten, Returns to Social Network Capital Among Traders, OXFord ECONOMiC PAPERS 54, 173-206 (2002).

226. John Locke, Second Treatise on Government, ch. 5. para 26. Locke's theories form the underpinning of the neo-classical economists' view of private property. 


\section{Benefits of the Anglo-American Model}

This model is very attractive to many for a number of reasons. First, it is attractive because it is familiar. Second, it is attractive because it puts a considerable amount of money into the hands of shareholders in a short amount of time. ${ }^{227}$ Thirdly, when the economy is growing well, the share values of these companies increase rapidly. ${ }^{228}$ Finally, its advocates a claim that it is the most efficient, although that claim is contested by none less than America's foremost corporate law scholar, John Coffee Jr. ${ }^{229}$ As noted, however, each model has not only strengths but also particular weaknesses.

\section{Weaknesses of the Anglo-American Model}

One problem of the Anglo-American model is that it causes a shortterm focus. The corporation's executives are more concerned about quarterly results and daily stock prices than the long term viability of the corporation. Not only may this short term executive focus be tied to corporate scandals, ${ }^{230}$ it also causes serious under-investment in capital expenditures that in turn undermine the long-term viability of the corporation. ${ }^{231}$ Such companies are vulnerable to becoming outmoded and to collapse, which in turn causes serious economic and social consequences. ${ }^{232}$ Most Anglo societies are able to deal with such collapses including corporate funded pension collapses, ${ }^{233}$ because their economies are sufficiently robust and they have adequate social security systems; ${ }^{234}$ however, given the demographic changes

227. Steven Kaplan, Corporate Governance and Corporate Performance: A Comparison of Germany, Japan and the U.S., chapter in Chew supra, note 225, at 253.

228. Kaplan's numerous studies are summarized in this chapter and he finds little difference except in terms of use of cash. Id. at 251-257.

229. John C. Coffee, et al., The Direction of Corporate Law: The Scholars Perspective, 25 DEL. J. CoRp. Law, 79, 93 (2000).

230. Krugman has referred to this as the lesson of the recent scandals, that we cannot bribe corporate officials to do their jobs. Paul Krugman has observed that options have been an important motivator in stock price manipulation. Paul Krugman, in his article The Outrage Constraint, NY Times. (Aug. 23, 2002), opines, "now it's clear that options were a big motivator for corporate fraud," in his Op-Ed piece, Enron and the System N.Y. Times (Jan. 9, 2004).

231. Michael E. Porter, Capital Disadvantage: America's Falling Capital Investment System. Harvard Bus. Rev. (Sept.-Oct. 1992).

232. The cost of the Enron debacle, for example, was in excess of $\$ 35$ billion.

233. M. Walsh, Failed Pensions: A Painful Lesson in Assumptions, N.Y. Times (Nov, 12, 2003).

234. Stiglitz notes this peculiarity of governments in developed economies, supra note 196 at 55. Stiglitz also notes that the lack of social security can be responsible for social unrest. He provides the recent examples in Indonesia, and Botswana, at 77 and 119. It should be noted, however, that many less developed economies have better social security programs, but simply lack the funds to put sufficient resources in them. 
and changes in fiscal policy, the strength and durability of such programs is questionable. ${ }^{235}$

Another problem with the Anglo-American model becomes evident when there is a broader economic downturn. As the world's foremost management professor Peter Drucker observed: "It is a fair weather model that works well only in times of prosperity." 236 In an economic downturn, Anglo-American corporations lay-off promptly their employees and as a result, in a recession many people are out of work. ${ }^{237}$ This approach to economic downturns is not too damaging to the employees or to the economy, again because of the previously mentioned social security system.

These strong social security systems help employees without jobs continue to pay mortgages, living expenses and other costs. This ability of laid-off employees to continue their basic consumption habits is critical to the Anglo-American economies because of their reliance on consumers. The US economy, for example, relies on consumers for two-thirds of its size and a great part of its activity.

Another problem arises from the Anglo-American model's ignoring other interests, or externalizing. Interests such as environment, social problems and employees have a cost which cannot be avoided. Although not taken into consideration in the Anglo-American model these costs must be paid in one way or another. ${ }^{238}$ To the extent that the Anglo-American corporation is forced to pay these costs, via the legal system, the Anglo-American way is very expensive. The contribution of legal services to the USA's economy is significant. ${ }^{239}$

Indeed, American corporations struggle under the burden of legal $\operatorname{costs}^{240}$ to the extent that nearly every legal reform program looks at

235. See changes to unemployment in Chicago's demographic Bob Herbert "Locked Out at a Young Age" N.Y. Times (Oct. 20, 2003). The extent to which this data can or should be extrapolated, is of course uncertain. Nevertheless, there needs to be some attention to the issues raised there.

236. P. Drucker, Will the corporation survive? Yes, but not as we know it, 360(8239) THE ECONOMist ( Sept. 15, 2001) at 16.

237. At the time of writing, the American unemployment figures suggest that 480,000 lost jobs in the last month in response to the protracted economic downturn, and discussion concerning a severely "jobless recover" suggest this may be more than a mere temporary problem.

238. Coase's Social Costs supra note 79 , deals with those costs caught by law; where law has not yet recognized such harms, for all economic and legal purposes, they fail to exist.

239. W. Stavropoulos, President of Dow Chemical Company, claimed that the costs of tort claim $2.2 \%$ of the GDP of the USA. This, of course, is not much of an argument if tort law works as it should: this is just the cost to the economy for corporate malfeasance through product liability.

240. See e.g., Interview with Valerie P. Hans, author of Business on Trial: The Civil Jury and Corporate Responsibility, 13:2 Bimonthly Review Of Law Books (Mar./Apr. 2002), available at http://www.law.suffolk.edu/faculty/ebander/index10-12-00.html. 
ways of making the system less costly. ${ }^{241}$ Not only is it very expensive, but it is questionable how efficient the system is in either paying externalized costs or preventing them in the first place. Indeed, it could be argued that many Anglo-American corporations operate with a "deferred costs" approach where corporations and corporate executives create costs-social, environmental and other costs-with the hope that they will not be discovered and enforced through the legal system until they have taken their profits and the shareholders have taken their profits. Such cases include the examples of the asbestos lawsuits that bankrupted the Johns Mansville Corporation ${ }^{242}$ and the recently launched employee suits for exposure to toxic chemicals while working in IBM chip manufacturing facilities, ${ }^{243}$ as well as the actions behind the collapses of Enron, Worldcom and Tyco among too many others.

In addition, it is important to note that the Anglo-American exclusion of other "stakeholder" interests has led to considerable anti-corporate backlash, which in part is behind the WTO and other antiglobalization protests. ${ }^{244}$ Anglo-American corporations are being forced by the Corporate Social Responsibility movement to expand their horizons and to spend money to include other concerns. The societies living with this model see the corporation as a destructive force in society which must be subject to a high level of regulation and control. ${ }^{245}$

241. S. Datta and J. Nugent have shown that for every increase of $1 \%$ in the number of lawyers in a society, economic growth suffers between about $4 \%$ cited in CoOTER, supra note 14 , at 79.

242. To cite but a few of the 600,000 suits against the corporation: Adams v. Johns-Manville Sales Corp., 783 F.2d 589 (5th Cir. 1986) Jackson v. Johns-Manville Sales Corp., 781 F.2d 394 , Gideon v. Johns-Manville Sales Corp., 761 F.2d 1129 (5th Cir. 1985), Thompson v. JohnsManville Sales Corp., 714 F.2d 581 (5th Cir. 1983), Prelick v. Johns-Manville Corp., 531 F. Supp. 96 (W.D. Pa. 1982), Hardy v. Johns-Manville Sales Corp., 509 F. Supp. 1353 (E.D. Tex. 1981). On the mass number of the suits, see Richard L. Cupp, Jr, ASBESTOS LITIGATION \& TORT LAW: TRENDS, ETHICS, \& SOLUTIONS: Asbestos Litigation And Bankruptcy: A Case Study For Ad Hoc Public Policy Limitations On Joint And Several Liability, 31 Pepp. L. Rev. 203(2003). Cupp observes that as many as 3,000,000 suits may be filed in the case, and according the right wing think tank, the RAND Corporation, supposedly the majority of people filing are not sick. This objection to such claims is odd for two reasons: first, how is one to know whether the litigants are or will be sick without the evidence, and second, tort claims may be for those who suffer loss of a family member as well as being made by injured parties themselves.

243. See also Bob Herbert, Clouds in Silicone Valley, N.Y. Times (Aug. 8, 2003).

244. Published by the Hemispheric Social Alliance. FTAA Exposed: A Citizens' Critique of the November 2002 Draft of the Free Trade Area of the Americas. http://www.cpdcngo.org/docs/ Shantal\%20documents/Partners\%20Perspectives\%20on\%20FTAA.doc

245. Regulation of Corporations is one important aspect of jury perspectives. See Donald E. Vinson \& David Perlut, The American Jury's View of Corporate America: It's Not A Pretty Picture, 7( 2) Briefly. . . Perspectives on Legislation, Regulation, and Litigation (Feb. 2003) published by National Legal Center for the Public Interest. From the opposite end of the 
Unlike enterprises in most other parts of the world, ${ }^{246}$ the AngloAmerican model of the corporation has traditionally been a collection of unrelated strangers who invest money together. It is run by a board of directors who represent only the interests of shareholders and management. One of the on-going problems for participants in this model is the constant effort to keep parties working together. ${ }^{247}$ Each party focuses exclusively on and fights for its own, limited self-interest above all else. It is an antagonistic, expensive model to manage. Indeed, much research has focused on minimizing the effects of the "agency problem"- the problem when investors and management are distant from each other and pursuing separate, different interests. ${ }^{248}$ Further, this animus is in part what drives the very expensive and of questionable benefit, market for corporate control.249

\section{Implications of the Anglo-American Model for Societies}

There are a number of significant implications that can be drawn from the Anglo-American model. This model may not be well suited to economies that are not robust. A large corporate collapse in a weaker economy can be expected to have significant repercussions which will be felt throughout the economy and result in unmanageable social costs. Furthermore, in many societies, workers do not have the benefit of a social security system. As a result, when the average worker in such a society loses a job, it is a crisis. Furthermore, if there is an economic downturn and workers do not have income to continue to spend, such an economy will have greater difficulty reviving. Simply the consumption necessary to keep the economy prosperous will not occur. Accordingly, the Anglo-American model which cuts jobs rapidly and drastically in economic downturns is not well suited to

political spectrum, see work by such authors as David Korten, When Corporations Rule THE WORLD.( 2ND ED. 2000).

246. Who is in charge? The Ins and Outs of Corporate Governance, The ECONOMIST, at 15-16. (Oct. 25, 2003).

247. This issue of agency costs which started with Berle and Means, has been carried forward in the work of Michael Jensen, William Meckling, O. Williamson \& W. C. Kester, Governance, Contracting, and Investment Horizons: A Look At Japan and Germany, chapter in Chew, supra note 225 , at 227.

248. Bainbridge notes that this issue is now passé for most law and economics scholars. See Stephen Bainbridge, The Politics of Corporate Governance, 18 Harv. J.L. \& Pub. Pol'y 671, 671.78 (1995) (reviewing Mark J. Roe, Strong Managers, Weak Owners: The Political Roots of AMERican Corporate Finance (1994)).

249. C.K. Prahalad, Corporate Governance or Corporate Value added? Rethinking the Primacy of Shareholder Value in CHEw, supra note 225, at 47-50. See also M. Mark Walker, On the Shareholder Wealth Maximization Objective of Corporate Governance: The case of Leveraged Recapitalizations, 22(4) Managerial Finance 53 (1996). 
many other economies, including possibly the United States of the future. 250

In its essence, the shareholder primacy model reflects particular American values: neo-classical economics and neo-liberal values. ${ }^{251}$ There are important consequences which flow from these American values, including increased wealth concentration, higher levels of unemployment, and some of the problems with corporate governance become exaggerated. Given some of the problems of the AngloAmerican model discussed, it is clear that there may be benefits to considering other models.

\section{B. German Model}

One of the European models which may offer some interesting alternatives is the German model. The German corporation is structured with a two tiered or "dual model" Board of Directors. 252 The executive board or "Vorstand" are management. The supervisory board, "Aufsichtsrat" is a split board with one section of the board of directors made up of shareholder nominated directors, and the other section of the board, being made up of employee nominated directors. ${ }^{253}$ It is interesting to note that in contrast to the Anglo-American model in which all directors are nominated by the shareholders and are professional managers, the directors nominated by German workers are there to represent them, and although usually professionally trained as economists or business scholars, they are not managers. ${ }^{254}$ This peculiar board structure is limited in its application to corporations which have more than two thousand employees-the "Mitbestimmungsgestz." Perhaps most interesting is that the operative executive board "Vorstand" is answerable not to the shareholders, but to the "Aufsichtsrat" or participatory supervisory board.

German corporations often invest money in training the worker nominated directors to help them become more effective in their roles as directors. This management training helps worker nominated directors to understand the management problems faced by the particular corporation. By investing in this training, the German corporations are able to get the maximum benefit from the worker

250. Walsh, supra note 234.

251. See Mark's interesting intellectual history reaching from 13th century theology to the 20 th century's view of the business corporation in the USA. Mark, supra note 127.

252. Gregory Alexander, Property as a Fundamental Constitutional Rights? The German Example, 88 CORNELL L. Rev. 733 (2003).

253. F. Schilling, Corporate Governance in Germany: The Move to Shareholder Value, 9(3) Corporate Governance 148 (2001).

254. Id. 
nominated directors, and the workers are more effective in communicating management concerns to workers and worker concerns to management. These directors work to protect workers' rights and interests.

Finally, German corporations tend to be financed by banks-that is, banks tend to be the major shareholders and indeed have accounted for some $90 \%$ of all external corporate finance. ${ }^{255}$ This shareholding pattern will be seen to have significant effects in the management of economic downturns.

\section{Benefits of the German Model}

Germany benefits from this model in two important strategic ways. First, there is less labour unrest. Unlike the Anglo-American model where parties are fighting against each other else in pursuit of their own self-interests, the German model functions better because it aligns management and worker interests in the larger, overall goal of advancing the corporation. Indeed, although German executives see problems with the boards, they would not wish to change it. ${ }^{256}$

The second advantage is that it puts the workers in direct touch with the management solving at least in part, two fundamental management problems-communication and trust. Management can understand worker complaints, concerns and suggestions more directly and easily. Workers sometimes have significant contributions to make to management of the corporation because of their very different perspective and hands-on experience with operations.

German corporations, given their ability to coordinate more interests have more parties interested in the corporation's survival. As a result, they tend to keep their investments in capital equipment up-todate, and have more secure long term outlooks. ${ }^{257}$ German companies tend to have longer strategic visions, less collapses, and are still very appealing to investors. ${ }^{258}$

Traditionally, German corporations are family businesses. ${ }^{259}$ The structure discussed reflects these family values and it seems to work well for those families. By including many more concerns German corporations have been highly successful not only in producing top

255. John Scott, Corporate Business and Capitalist Classes, 145-146 (1997).

256. Schilling, supra, note 254, at 149.

257. Id. at 150.

258. Id.; Scott, supra note 256, at 147-149.

259. See Who is in Charge, The ECONOMIST, supra note 196, and Scott, supra note 256, at 146 147. 
quality products, but they have been able to do so in a competitive environment.

\section{Drawbacks of the German Model}

Effective use of this model requires an egalitarian view of humanity. Whether presidents of companies or workers on the factory floor, the view must be that humans are valuable, intelligent and willing contributors to overall group achievement. Furthermore, management needs to have a confidence that workers have the intelligence and goodwill to contribute. The overly simple $x-y$ theory of organizational behaviour has to be rejected. ${ }^{260}$ Finally, the model requires at least a minimal level of sophistication among workers.

\section{Japanese Model}

Another corporate model of interest is the Japanese model. Japanese corporate law and practice is an interesting mix of German, traditional Japanese, and American law. ${ }^{261}$ In some ways, Japanese corporate law has drawn the best of each of the systems. It is important to note that although Japanese corporate law was established in 1950 by the occupying US forces, to create corporate law the US has basically translated and planted the Model Business Corporations Act into the Japanese legal system. Thus, although at a legal level Japan has American corporate law, Japanese corporations have largely ignored the law and operated their corporations on the basis of extralegal norms. ${ }^{262}$ In practice, then, Japan has developed its own corporate law. ${ }^{263}$ Since it is these norms have driven corporate development in Japan more than the law, the relevant discussion focuses on the model set out by the norm rather than the law.

The Japanese model has rejected Anglo-American "shareholder primacy" model. In fact, in the Japanese model, shareholders interests are among the least important of the interests to be considered. ${ }^{264}$

260. McGregor's Theory $X$ and Theory $Y$ initially set out in his, Douglas McGregor, The Human Side of EnTERPrise (1960).

261. Mark W. West, The Puzzling Divergence Of Corporate Law: Evidence And Explanations From Japan And The United States, 150 U. PA. L. REv. 527, 538 (2001).

262. See discussion Curtis Milhaupt, Symposium Norms \& Corporate Law: Creative Norm Destruction: The Evolution of Nonlegal Rules in Japanese Corporate Governance, 149 U. PA. L. REv. 2083 (2001).

263. See Id.

264. John Farrar, Corporate Governance in Australia and New Zealand 34 (2001). The reluctance of Korean and Japanese managers to lay off employees and the resultant benefit to the employees is noted in Stiglitz, supra note 196, at 57. 
Japanese priorities are: the corporation itself, customers, employees, creditors and finally, shareholders. ${ }^{265}$

The Japanese model is based on the village system where everyone worked together for common survival and the common good. 266 Accordingly, as noted, Japanese executives have given a higher priority to employees' interests than to shareholder interests. One example of that priority is the Japanese corporate policy lifetime employment. ${ }^{267}$ While it is changing, it is interesting to note that the Japanese corporation has managed to survive in very difficult economic times. This employee priority has created significant benefits for Japanese society.

\section{Benefits of the Japanese Model}

What is particularly interesting about the Japanese modelled corporation is how it has buffered society from economic crisis, by addressing the interests excluded by the Anglo-American model. It is interesting because Japan has experienced one of the most severe economic declines in the history of the world with its society relatively in tact.

Japan's economy has been in recession, if not depression, for over ten years. ${ }^{268}$ The Japanese economy has shrunk more in the last ten years than the American economy did in the Great Depression of the 1930 's. ${ }^{269}$ Despite this economic decline, the average Japanese worker has been able to go on living without experiencing the devastating loss of employment that characterized the American workers' experience in the Depression. Unlike America which acquiesced to creating the hobos and communities hobbled by broken families caused by the unemployment of the Great Depression, ${ }^{270}$ Japan has been much more

265. See Toshiba Chairman, Joichi Aoi, To Whom Does the Company Belong?: A New Management Mission for the Information Age, in Chew, supra note 225, at 247.

266. Kenichi Ohmae, The Mind of The Strategist 218-19 (1982). Milhaupt claims the model is not the village but the family. There is some controversy about this view as it generally accepted that many of the norms discussed here are post-World War II inventions. See L. Nottage \& L. Wolff, Corporate Governance and Law Reform in Japan: From the Lost Decade to the End of History? in R. HAAK ET al (eds), Japanese Management: In Search of New BalanCe between Continuity and Change (Forthcoming).

267. Milhaupt supra note 263.

268. Finance and Economics: Checking the Slumpometer; Economics Focus, 362 THE EconoMIST 91 (Mar. 2, 2002). At the time of writing this article, it appears that Japan's economy may be recovering. See Nottage, supra note 267.

269. Id. Contrary view is expressed by Paul Krugman whose observes that Japan's last decade has not been as severe, losing only in 2 of the last 10 years, and that the benefit received by the average workers is due to government's public works projects. Paul Krugman, The Great UNRAVELING 95 (2003). See references supra note 182.

270. The American experience of the time was immortalized by JoHn STEINBEck, THE GRAPES OF WRATH-an excellent reminder of the situation for the average family in that time. 
successful than America in keeping the ravages of a severe economic downturn from destroying people and communities. People still have jobs, there is no threat of rebellion, consumers can still buy and the economy continues to work because of its consumers even though it continues to suffer severe problems. ${ }^{271}$

By way of contrast, in the Great Depression of the 1930's, American society suffered greatly. Its workers had no money to spend and vast multitudes were reduced to utter poverty. Unlike the AngloAmerican model which passed the costs of the economic decline directly onto the employees, the Japanese corporate model passes the costs of the decline to the shareholders and institutional lenders. ${ }^{272}$ Indeed, in Japan nearly all the economic fluctuations have been borne by shareholders who have invested excess funds ${ }^{273}$ as opposed to employees whose life's work and day-to-day livelihood are dependent on their on-going employment. ${ }^{274}$ Japan's legendary low unemployment figures are a reflection in part of this model. ${ }^{275}$

A further benefit may be its efficiency (opinion is quite varied on the efficiency of Japanese corporations, depending on how one looks at it). One area of efficiency is in the access that shareholders and institutional investors have to information about corporate performance. They have much better and more direct access, and interestingly, studies show that they act to remove inefficient managers at least as quickly as European and US counterparts. ${ }^{276}$ Another area of efficiency is in the very limited market for corporate control. This market while supposed to improve market efficiency, is notoriously

It is hard to imagine anyone reading that work and puzzling whether families in poverty are more concerned about efficiency in the market for corporate control and greater overall wealth, or the need for a basic income.

271. The rate of Japanese unemployment has reached a record high of $5.2 \%$, something shareholder primacy model economies and governments normally only dream of. See Fin. Times 1 (Apr. 25, 2003). As well, this is a source of inefficiency referred to as "excess manpower." Kester, supra note 248, at 260.

272. See e.g., R. Wade, Joe Stiglitz's Bum Rap, 25:5 J. of Policy Modeling (2003).

273. Or savings. I use the term "excess funds" to emphasize that these funds are not needed for day to day living, and hence, "excess."

274. Murray Dobbin, The Myth of the Good Corporate Citizen 74 at note 29 (1998) (citing Columbia University economist Frank Lichtenberg, In a Downturn, Cut Profits Before Jobs, N. Y. TIMEs 13 (Feb. 16, 1992).

275. Recent unemployment figures for Japan are 5.2\% "Japan PM: Economy emerging from slowdown," Monday, January 5, 2004 - Associated Press, compared to United States' current accurate figure of nearly 9.2\%, Bob Herbert, The White-Collar Blues, N.Y. Times (Dec. 29, 2003).

276. Kester, supra note 248, at 239. 
expensive, and of questionable long-term value.277 In Japan it is nearly non-existent. 278

\section{Drawbacks of the Japanese Model}

The main problem with the Japanese model is that the support provided by the collectivist approach makes it difficult to deal effectively with underperforming assets. ${ }^{279}$ Japanese corporate restructurings do not cut costs, or change much in the corporation other than the management team. ${ }^{280}$ Japanese corporations tend to hold onto their cash instead of reinvesting it into the economy. ${ }^{281}$ Furthermore, the Japanese system tends to burden suppliers and entrepreneurs with the debts of failed businesses. 282 In summary, the main drawback is that Japanese corporations do not have the same level of efficiency in other areas. ${ }^{283}$ Nevertheless, while some economists have argued that Japan's model has not made the most efficient use of economic resources, ${ }^{284}$ as we have seen, at least to the Japanese, efficiency is not the measure of all things.

\section{Implications of the Japanese Model for the Future}

The Japanese model offers some very attractive alternatives for keeping an economy and society functioning during difficult economic times. Even more appealingly, the model does so without undue stress on the government treasury. Many governments are not wealthy and have difficulty meeting even their basic social security obligations. By forcing the corporation to internalize more of these

277. Walker, supra note 200 ; Kester, supra note 248 , at 239 . See for a very thorough specific industry example of financial institutions, which should be the best evidence of the claim made for the market for corporate control, Robert DeYoung, Bank Mergers, X-efficiency, and the Market for Corporate Control, 23 (1) MANAGERIAL FIN. 32 (1997), and the general opinion that it does not work as a basis for precluding it from developing in Less Developed Countries, in Ajit Singh \& Bruce A Weisse, Emerging Stock Markets, Portfolio Capital Flows and Long-Term Economic Growth: Micro and Macroeconomic Perspectives, 26(4) WORLD DevelopMENT 607 (Apr. 1998).

278. See Nottage, supra note 267.

279. Noted in Wade, supra note 273.

280. $I$ d.

281. Kester, supra note 248 , at 260.

282. K. Aichi \& K. Yakushiji, Can Japan's Politics Save Japan's Economic Troubles?, Center For Strategic \& International Studies, Feb 27, 2002, available at http://www.csis.org/japan/ 020227aichi.pdf.

283. Aoi, supra note 217, at 245.

284. The argument is made that the market for corporate control is stifled by the cooperation of companies with each other reducing efficiency by keeping afloat companies that should be in bankruptcy. See e.g., Economist Mar. 2002 in which the banking argument is made. 
costs, workers and society can be spared the worst effects of economic downturns.

\section{Visions of the Future}

\section{A. Peter Drucker}

Peter Drucker, as previously indicated, is arguably the world's foremost management theorist. He suggests in his provocative article, "Will the Corporation Survive? Yes, But Not As We Know It" that in the foreseeable future there will be some profound changes to the corporation. Drucker opines that the corporation will increasingly rely on a few professional managers whose power will increase exponentially. The majority of the work will be out-sourced to tightly controlled suppliers. This "dispersed model" of the corporation poses significant challenges for the legal and financial system, not to mention society as a whole. The "dispersed model" with its higher concentration of power and corollary lower level of participation exponentially increases the risks of managerial abuse of power, both in terms of financial malfeasance, and in the political arena.

Drucker notes that this "dispersed model" is not new but has historical precedents in Europe. What is new, however, is the context in which it now occurs-a loose non-affiliated corporate culture. This dispersed model also has parallels in multinational corporations. While some scholars fear that the regulatory issues ${ }^{285}$ raised by multinationals may ultimately prove to be insurmountable, ${ }^{286}$ the multinational and the regulatory problems they pose appear to be here to stay, and if Drucker is correct, we may see more of the same type of problems in the domestic market. Future legal developments must take this into account and should be forward looking anticipating some of the issues this will raise. Of course, law is a backwards looking enterprise examining previous cases and old doctrines. This orientation makes the future doubly challenging.

\section{B. Michael Jensen}

Another important business thinker, Michael Jensen, wrote an even more radical article entitled, "Eclipse of the Public Corporation."287 While Jensen's predictions have turned out to be nearly completely incorrect - his hypothesis of a dramatic increase of leveraged buy-outs

285. DiNE, supra note 3.

286. See e.g., J.Dine, \& J. Dunning, Governments, Globalization, and International Business (1999).

287. M. Jensen, Eclipse of the Public Corporation, Harvard Bus. Rev. 61 (Sept. 1989). 
has not been borne out-his article bears merit in that it points out the possibilities for a similar concentration of power. If such power is available for an extended time in the marketplace, what risks does it create for the economy in terms of creating monopolies of power, further corruption of government by special interest groups, and concentration of wealth and resources? ${ }^{288}$ These are important issues given the social wealth justification for the shareholder primacy model corporation on the one hand and the increasingly skewed distribution of society's resources through concentrations on the other. ${ }^{289}$

\section{CONClusion}

Each of the models of the corporation is informed by and heavily dependent upon values. It is imperative that the values incorporated in each of the models be put forth and made the centre of the debate. ${ }^{290}$ To fail to do so is to permit the incomplete work of the positivist neo-classical economist to create a normative vision for society. It permits the considerations of wealth to determine the path of humankind. A wealth focus offers no justice, no hope and ultimately undermines our humanity. As long as humans hold anything other than wealth maximization dear, the need to permit law, indeed to incite law, to include other values and form society must exist and the value of economic analysis kept in its place. Law has considerable ground to cover both in theory and in its development even to reach today, and increasingly central to law's mandate as the guardian of justice, hope and society is this issue of corporate modelling.

288. Interestingly, this concentration has occurred in both Germany and Japan, but perhaps in part because of the models discussed, the impact has not been as negative. Jensen observed that the bought-out corporations were usually returned to the public market within a few years.

289. Distributive justice is a primary concern for lawyers and a secondary concern, at best, among economists. Economists deal with this issue as secondary to the primary objective of increasing wealth. The wisdom and acceptability of this approach is coming increasingly under attack even among economic scholars. See for example, the new journal, the Journal of Economic Inequality.

290. As Michael Bradley, et al, observe, "The deepest challenge then is to find a way to enact communitarian sentiments in a contractarian world." in The Purposes and Accountability Of The Corporation In Contemporary Society: Corporate Governance At A Crossroads, 3(9) LAw AND Contemporary Problems 62 (1999). 
